\title{
Endometriosis - insights into a multifaceted entity
}

\author{
Cornelia Amalinei ${ }^{1, *}$, Ioana Păvăleanu ${ }^{1, *}$, Ludmila Lozneanu', Raluca Balan', \\ Simona-Eliza Giuşcă², Irina-Draga Căruntu ${ }^{1}$
}

\author{
${ }^{1}$ Department of Morphofunctional Sciences I - Histology, “Grigore T. Popa” \\ University of Medicine and Pharmacy, Iaşi, Romania \\ ${ }^{2}$ Department of Morphofunctional Sciences I - Pathology, "Grigore T. Popa" \\ University of Medicine and Pharmacy, Iaşi, Romania \\ *Both authors equally contributed to this paper
}

\begin{abstract}
Firstly described at the end of nineteenth century, endometriosis remains an enigmatic disease, from etiopathogenesis to specific markers of diagnosis and its ability to associate with malignancies. Our review has been designed from a historical perspective and steps up to an updated understanding of the disease, facilitated by relatively recent molecular and genetic progresses. Although the histopathological diagnosis is relatively simple, the therapy is difficult or ineffective. Experimental models have been extremely useful as they reproduce the human disease and allow the testing of different potential modulators or treatment options. Due to molecular resemblance to carcinogenesis, applications of anti-cancer agents are currently under scrutiny. The desired goal of an efficient therapy against symptomatic disease, along with associated infertility and malignancies, needs a deeper insight into the complex mechanisms involved in endometriosis initiation, development, and progression. Current trends in genomic and proteomic approaches are useful for a more accurate classification and for the identification of new therapeutic targets. (Folia Histochemica et Cytobiologica 2018, Vol. 56, No. 2, 61-82)
\end{abstract}

Key words: endometriosis; retrograde menstruation; cytokines; angiogenesis; apoptosis; precursor lesion; carcinogenesis; anti-cancer agents

\begin{abstract}
Abbreviations: 5-FU - 5-fluorouracil; 8-OHdG - 8-Oxo-2'-deoxyguanosine; ACP1 - acid phosphatase 1; ALCAM/CD166 - activated leukocyte cell adhesion molecule/cluster of differentiation 166; ANXA4 - annexin A4; ARID1A - AT-rich interaction domain 1A; AKT - serine/threonine kinase or protein kinase $\mathrm{B}[\mathrm{PKB}]$; Bax - BCL-2-associated $\mathrm{X}$ protein; BCL-2 - B-cell lymphoma 2; bFGF - basic fibroblast growth factor; BRAF - B-raf proto-oncogene, serine/threonine kinase; BRCA — breast and ovarian cancer susceptibility protein; $\mathrm{C}$-complement component; CA-125 - cancer antigen 125; CA 19-9 - cancer antigen 19/9; CAMs - cell-adhesion mol-
\end{abstract}

Correspondence address: Prof. I.-D. Căruntu

Department of Morphofunctional Sciences I,

"Grigore T. Popa" University of Medicine and Pharmacy,

16, University Street, Iaşi, 700115, Romania

tel.: 0040-727003700

e-mail: irinadragacaruntu@gmail.com ecules; CETP - cholesteryl ester transfer protein; $\mathrm{CD}$ - cluster of differentiation; Cdk - cyclin-dependent kinase, $\mathrm{CK}$ - cytokeratin; CLI - chloroindazole; COX-2 - cyclooxygenase-2; CTNNB1 - catenin (cadherin-associated protein) beta 1; CYP12A1 - cytochrome P450 family 17 subfamily A member 1 ; DAPK1 - death-associated protein kinase 1; DNA - deoxyribonucleic acid; DRD2 - dopamine receptor D2; E2 - estradiol; EGF - epidermal growth factor; EMT - epithelial-mesenchymal transition; ENDO-I - endometriosis protein-I; ENG - endoglin; eotaxin (CCL11) - C-C motif chemokine 11; EP - prostanoid receptor (prostaglandin E receptor); ER - estrogen receptor; ERK - extracellular signal-regulated kinases; EZH2 - enhancer of zeste homolog 2; FasL - Fas ligand; FGF-9 - fibroblast growth factor 9; FGFR - fibroblast growth factor receptor; FOXP3 - forkhead box P3; FSH - follicle-stimulating hormone; Gn-RH - gonadotropin-releasing hormone; GROa (CXCL1) - chemokine 
(C-X-C motif) ligand 1; GSTM1 - glutathione S-transferase mu 1; GSTT1 - glutathione S-transferase theta 1; HER-2 - human epidermal growth factor receptor 2; HGF - hepatocyte growth factor; HIF- $1 \alpha$ - hypoxia-inducible factor 1 alpha; sHLA-G — soluble human leukocyte antigen G; hMLH1 — human mutL homolog 1 ; HNF1- $\beta$ - hepatocyte nuclear factor 1 homeobox B; hTERT - human telomerase reverse transcriptase; ICAM - intercellular adhesion molecule; IFN- $\gamma$ - interferon gamma; Ig — immunoglobulin; IGF - insulin-like growth factor; IL - interleukin; ITGB1 - integrin beta- 1 precursor; JAK - Janus kinase; KRAS - Kirsten rat sarcoma viral oncogene homolog; LFA-1 - lymphocyte function-associated antigen 1; $\mathrm{LH}$ - luteinizing hormone; $\mathrm{LOH}$ - loss of heterozygosity; MCAM - melanoma cell adhesion molecule; MCP-1 - monocyte chemotactic protein 1; MEK - mitogen-activated protein kinase; MIF - macrophage migration inhibitory factor; miRNA - microRNA; MLH1 - human MutL homolog 1; MMP — matrix metalloproteinase; $\mathrm{MoAb}$ - monoclonal antibody; MSC - mesenchymal stem cell; mTOR - mechanistic target of rapamycin; MT5-MMP - membrane-type 5-MMP; MVD - microvascular density; NF $\kappa \mathrm{B}-1$ - nuclear factor of kappa light chain enhancer in B-cells; NK - natural killer; OBHS - oxabicycloheptene sulfonate; Oct-4 - octamer-binding transcription factor 4; $\mathrm{P} 4$ - progesterone, $\mathrm{PAI}$ - plasminogen activator inhibitor; PD-ECGF - platelet-derived endothelial cell growth factor; PDGF - platelet-derived growth factor; PDGFRB - platelet-derived growth factor receptor beta; PDTC - pyrrolidine dithiocarbamate; PGE2 - prostaglandin E2; PGF - placental growth factor; PGP9.5 - ubiquitin C-terminal hydrolase L1; PI3K - phosphatidylinositol 3-kinase; PI3KCA - phosphatidylinositol-4,5-bisphosphate 3-kinase catalytic subunit alpha; PPAR- $\gamma$ - peroxisome proliferator-activated receptor gamma; $\mathrm{PR}$ - progesterone receptor; PTEN - phosphatase and tensin homolog; PTPN22 - protein tyrosine phosphatase, non-receptor type 22; r-hTBP-1 - recombinant human tumor necrosis factor binding protein-1; RANTES (CCL5) - chemokine (C-C motif) ligand 5; SDF1 (CXCL12) - C-X-C motif chemokine ligand 12; sICAM - soluble intercellular adhesion molecule 1; SMAD - mothers against decapentaplegic homolog 1 (Drosophila); StAR — acute steroidogenic regulatory protein and aromatase; STAT — signal transducer and activator of transcription; TGF- $\beta$ - transforming growth factor beta; Th - T helper cells; TIMP — tissue inhibitor of metalloproteinase; TNF- $\alpha$ - tumor necrosis factor alpha; TNFR - tumor necrosis factor receptor; TSG - tumor suppressor gene; TSH
- thyroid-stimulating hormone; uPA - urokinase-type plasminogen activator; VEGF — vascular endothelial growth factor; VEGFR - vascular endothelial growth factor receptor; WNT4 — wnt family member 4; WT1 — wilms tumor 1; ZNF217 — zinc finger protein 217

\section{Introduction: definition and epidemiology}

The first histopathological description of endometriosis was given by Von Rokitansky, as early as 1860 [1]. By 1896, the name of "endometriomas" or "adenomyomas" had been proposed, due to the lesion resemblance to the mucous membrane of the uterus [2,3].

Endometriosis is nowadays defined as an ectopic implantation of endometrial-like tissue, composed of both glands and stroma. Endometriosis has an incidence of about $2 \%$ in general population [4], with numerous incidental occurrences, approximately $70 \%$ of cases developing pelvic inflammatory disease, and $25-30 \%$ of cases being associated with infertility [5].

Endometriosis mainly involves the reproductive tract components (in about $75 \%$ of cases), such as ovaries, fallopian tubes, large, round, and uterosacral ligaments, uterine cervix, vagina, and recto-vaginal septum [5]. In about $25 \%$ of cases, this process may be identified in extra-reproductive organs, especially with intraperitoneal locations (peritoneum, Douglas pouch, appendix, gastro-intestinal tract, and lymph nodes) [6]

Rare extraperitoneal locations are also reported in literature, such as liver [7], lung [8], pleura or diaphragm [9], urinary tract [10], tegument, mainly post-surgical abdominal scars, i.e. post $\mathrm{C}$-section, nasal cavity [5], iliac vein wall [11], and hernial sac wall [12].

Although it is considered a benign disease, the endometrium acquires aggressive pathological characteristics, being able to migrate, implant, proliferate, and grow in other sites than those genetically established, during endometriosis development.

\section{Clinico-histopathological features}

Endometriosis is a highly heterogeneous entity due to different degrees of clinical manifestations, with a broad spectrum, from symptomatic cases, manifested mainly with characteristic cystic lesions and adherences, to symptomatic cases although without evident lesions, and to incidentally discovered, asymptomatic cases.

Gross findings are also highly variable, from small dispersed lesions, such as superficial or "gunpowder" 


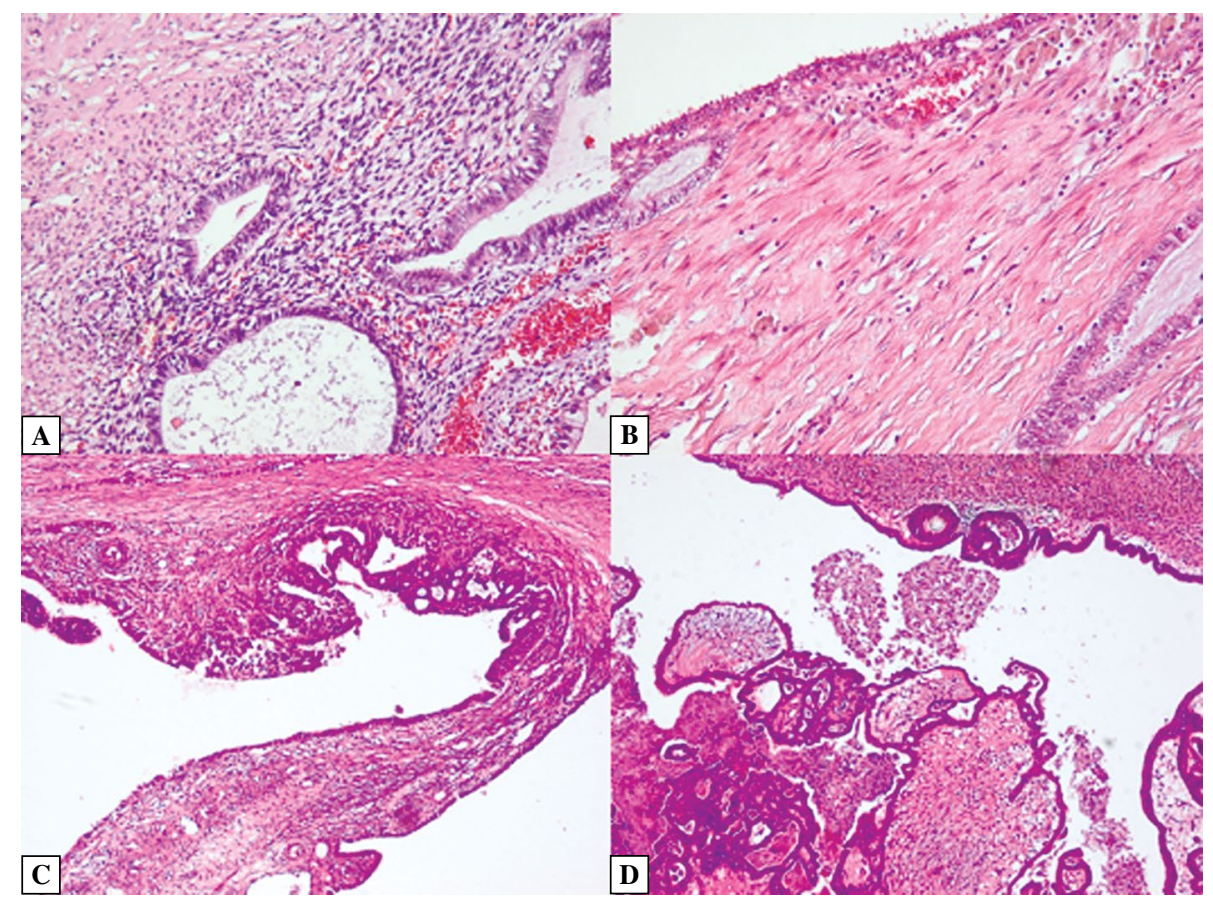

Figure 1. Distinct histological features of endometriosis. (A) Ovarian endometriosis containing endometrial glands and stroma in an ectopic (ovarian) location (HE, 200×). (B) Ovarian endometriosis with evident hemosiderin-laden macrophages (HE, $200 \times$ ). (C) Ovarian endometriosis associated with an area of atypical endometriosis, with a complex architecture $(\mathrm{HE}, 40 \times)$. (D) Ovarian endometriosis (upper field) associated with endometrioid carcinoma (inferior) (HE, $40 \times$ ).

appearance, to cystic, red implants, or petechiae, vesicles, nodules, and, sometimes, polyps, depending on their location, duration, and association with fibrous adhesions [13].

A combined anatomical and histopathological classification recognizes three main types of endometriosis: endometrioma, peritoneal, and deep infiltrative lesions [9].

Endometrial cysts or endometriomas usually involve the ovaries, exhibit bilateral location in around one third of cases and develop until almost completely replacing the ovarian parenchyma [13]. They are most commonly associated with fibrous walls, adherences to neighboring structures, and usually chocolate-colored inspissated or semifluid content [13]. If larger than $15 \mathrm{~cm}$ in diameter or associated with polypoid projections or solid areas, a developing neoplasm should be considered [13].

Peritoneal endometriosis may involve (in decreasing order of frequency): ovaries (30\%), uterosacral and large ligaments (18-24\%), fallopian tubes (20\%), pelvic peritoneum, Douglas pouch, and gastro-intestinal tract $[5,6]$.

Deep infiltrative endometriosis has been identified in $30-40 \%$ of patients diagnosed with endometriosis [5], involving pelvis and gastrointestinal tract [6].

Histopathological findings have been based on the identification of endometrial glands surrounded by characteristic cellular stroma (Fig. 1A), registering an analogous pattern to the eutopic endometrial cycle.

Although histopathological diagnosis can be relatively simply reached, the microscopic differentials with ovarian endosalpingiosis [13], a lesion frequently overdiagnosed as endometriosis, has to be made. This may be achieved by the identification of a stromal inflammatory infiltrate, containing variable amount of lymphocytes, a reduced number of other inflammatory cells, with evident hemosiderin-laden macrophages (Fig. 1B), as proof of a cyclic evolution of the ectopic tissue, although a ceroid pigment may occasionally confer a pseudoxanthoma appearance to these cells [13]. Rarely, benign cystic lesions or even well differentiated adenocarcinomas may be included in the differential diagnosis. Currently, immunohistochemical profile may be useful, by CD10 strong stromal positivity, $\mathrm{ER} \beta$ and PR-A variable epithelial and stromal positivity, along with Bcl-2 and Ki-67 epithelial and stromal positivity correlated to the size of the implant, supplementing the histological characteristics exhibited in routine staining [14].

The accumulation of data on endometriosis has been facilitated by comparative studies between native and experimental disease, due to a close resemblance of both laparoscopic findings and microscopic patterns demonstrated between animal models and their corresponding human disease [15]. 


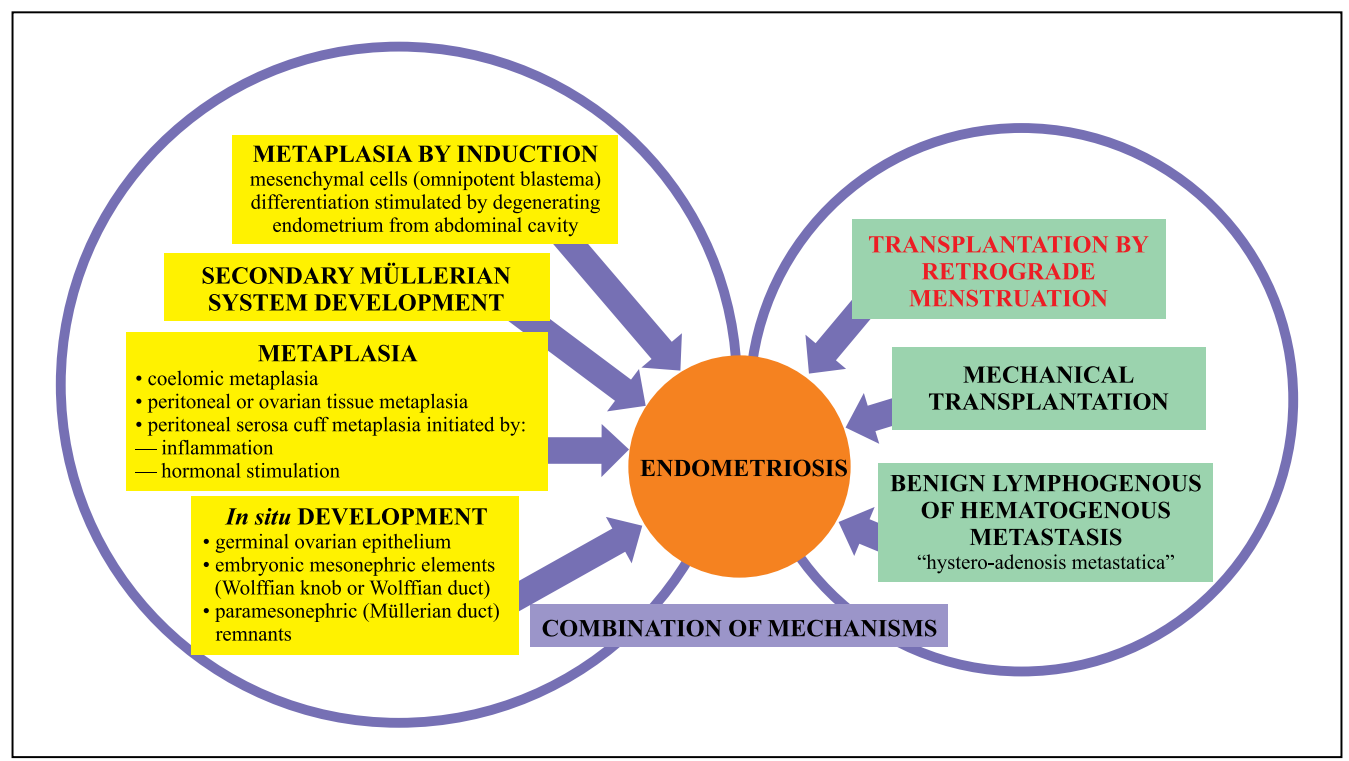

Figure 2. Etiopathogenic theories of endometriosis: from past to current concepts and combination of theories. Detailed description in the main text.

\section{Markers for diagnosis}

The specific markers of endometriosis may be classified into three main categories (Table 1): (i) peritoneal and/or serum, (ii) endometrial and biochemical-endometrial, and (iii) genetic types.

Peritoneal and/or serum markers are grouped into several categories, as follows: glycoproteins [16-19], growth factors [18, 20-27], proteolytic enzymes and their specific inhibitors [28-32], soluble adhesion molecules [33-37], hormones [38-43], cytokines [42, 44-57], autoantibodies [58, 59], and environmental contaminants [60]. The diagnostic value of some of these markers has been quantified and, as a result, two peritoneal and/or serum cytokines may be useful in the diagnosis of endometriosis, such as increased serum IL-6 (threshold of $2 \mathrm{pg} / \mathrm{ml}$ ) [49], and serum or peritoneal fluid TNF- $\alpha$ (threshold of $15 \mathrm{pg} / \mathrm{ml}$ ) [49], although conflicting results are reported in possible correlation with disease stage, location, endometrial cycle phase, control groups, and assay type [49].

The endometrial and biochemical-endometrial markers are considered as stromal [61, 62], glandular [62-64], neuronal [65], proteolytic enzymes and their specific inhibitors [28-31, 66-70], adhesion molecules [34, 62, 71-74], osteopontin [75], hormonal receptors [38, 39, 76-80], and mesenchymal stem cells [81-85].

Genetic markers belong to variable categories, such as: oxidative stress genes [86], tumor suppressor genes [87-98], oncogenes [90, 99-103], regulatory genes [104, 105], DNA repair genes [93], chromosomal aberrations or amplifications [106-108], loss of heterozygosity [87, 107, 109], genetic polymorphism of variable genes [107, 110-119], and genome-wide alterations [120, 121].

The prospective clinical validation of these markers and determination of their clinical utility may lead to the development of a successful commercial test for endometriosis diagnosis.

\section{Past to rediscovered etiopathogenic theories and recent contributions}

\section{Short overview - historical hallmarks}

Endometriosis is considered as the "theories disease", taking into account numerous past and modern etiopathogenic hypotheses which have been launched during a long period of attempts to explain its nature $[4,9]$ (Fig. 2).

According to the past theories, endometriosis may result by in situ development from germinal ovarian epithelium [122], from embryonic mesonephric elements (Wolffian knob and Wolffian duct) [9], or from paramesonephric (Müllerian ducts) remnants [3, 9, 123].

Other hypotheses are those of metaplastic processes, as coelomic metaplasia $[9,124-126]$, or metaplasia of the peritoneal or ovarian tissue [127, 128], or metaplasia of the peritoneal serosa cuff initiated by inflammation $[9,129]$ or by hormonal stimulation [130]. The possibility of metaplasia development, by differentiation of mesenchymal cells (omnipotent blastema) activated by substances released by degenerating endometrium eliminated into the abdominal cavity, has been also proposed [131, 132]. 
Table 1. Spectrum of markers in endometriosis diagnosis and follow-up

\begin{tabular}{|c|c|c|}
\hline Peritoneal and/or serum markers & Endometrial markers & Genetic markers \\
\hline $\begin{array}{l}\text { Glycoproteins } \\
\text { CA-125 [16-19], CA 19-9 [18] }\end{array}$ & $\begin{array}{l}\text { Stromal } \\
\text { CD10 [61], Vimentin [62] }\end{array}$ & $\begin{array}{l}\text { Oxidative stress } \\
8-\mathrm{OHdG},[86]\end{array}$ \\
\hline \multirow{3}{*}{$\begin{array}{l}\text { Growth factors } \\
\text { EGF(R) [20], TGF- } \beta \text { [21], SF/HGF [22] } \\
\text { FGF-9 [23], VEGF [20, 24], } \\
\text { Angiopoietins [25], } \\
\text { Glycodelin [26, 27] }\end{array}$} & $\begin{array}{l}\text { Glandular } \\
\text { CK18 [62] } \\
\text { Glycodelin }[63,64]\end{array}$ & $\begin{array}{l}\text { Tumor suppressor genes } \\
\text { PTEN [87-89], P53 [90, 91], P16 [92, 93], } \\
\text { ARID1A [94-96], } \\
\text { WT1 [97], DAPK1 [98] }\end{array}$ \\
\hline & \multirow[t]{2}{*}{$\begin{array}{l}\text { Neuronal } \\
\text { PGP9.5 [65] }\end{array}$} & $\begin{array}{l}\text { Apoptosis } \\
\text { Bcl-2 (anti-apoptotic) }[90,99,100] \\
\text { Survivin (anti-apoptotic) }[101]\end{array}$ \\
\hline & & $\begin{array}{l}\text { Oncogenes } \\
\text { HNF1- } \beta \text { [102], KRAS [103] }\end{array}$ \\
\hline \multirow{3}{*}{$\begin{array}{l}\text { Proteolytic enzymes and their specific } \\
\text { inhibitors } \\
\text { MMPs/TIMPs [28-31] } \\
\text { Cathepsin D [32] }\end{array}$} & \multirow{3}{*}{$\begin{array}{l}\text { Proteolytic enzymes and } \\
\text { their specific inhibitors } \\
\text { MMPs/TIMPs [28-31, 66-69] } \\
\text { plasminogen activators / plasminogen } \\
\text { activator inhibitors [70] }\end{array}$} & $\begin{array}{l}\text { Regulatory genes } \\
\text { PIK3CA, FGFR [104, 105] }\end{array}$ \\
\hline & & $\begin{array}{l}\text { DNA repair } \\
\text { hMLH1 [93] }\end{array}$ \\
\hline & & $\begin{array}{l}\text { Chromosomal aberrations } \\
\text { aneusomies (chrs. 1, 7, 9, and 17) } \\
{[106,107]}\end{array}$ \\
\hline \multirow{2}{*}{$\begin{array}{l}\text { Soluble adhesion molecules } \\
\text { E-cadherin, P-cadherin, } \beta \text {-catenin }[33,34] \\
\text { ICAM-1 [35] } \\
\text { sHLA-G [36] } \\
\text { Osteopontin [37] }\end{array}$} & $\begin{array}{l}\text { Cell adhesion molecules } \\
\text { E-cadherin, P-cadherin, CD44 [34, 62, } \\
71-74]\end{array}$ & $\begin{array}{l}\text { Chromosome amplification } \\
\text { 20q13.2, 12p12.1, 17q12, 9p21 [108] }\end{array}$ \\
\hline & Osteopontin [75] & $\begin{array}{l}\text { Loss of heterozygosity } \\
4 \mathrm{q}, 5 \mathrm{q}, 6 \mathrm{q}, 9 \mathrm{p}, 11 \mathrm{q}, 22 \mathrm{q} \\
10 \mathrm{q} 23.3,17 \mathrm{p} 13.1[87,107,109]\end{array}$ \\
\hline $\begin{array}{l}\text { Hormones } \\
\text { E2, P4 [38, 39] } \\
\text { FSH, LH, TSH [40] } \\
\text { Leptin [41-43] }\end{array}$ & $\begin{array}{l}\text { Hormonal receptors } \\
\text { ER- } \beta, \text { ER- } \beta \text { :ER- } \alpha \\
{[38,39,76,77]} \\
\text { PR-A [78] } \\
\text { FSHR, LHR }[79,80]\end{array}$ & $\begin{array}{l}\text { Genetic polymorphism candidate genes } \\
\text { TP53 (17p13) [107] } \\
\text { VEGF (6p21-12) [110] } \\
\text { ACP1 (2p25) [111] } \\
\text { PTPN22 (1q13) [112] } \\
\text { DRD2 (11q32) [113] } \\
\text { FOXP3 (Xp11.23) [114] } \\
\text { GSTM1 (1p13) [115] } \\
\text { GSTT1 (22q11) [115] } \\
\text { IL-10 (1q31-32) [116] } \\
\text { CETP (16q21) [117] } \\
\text { TNF-A (6p21) [118] } \\
\text { CYP17A1 (10q24) [119] }\end{array}$ \\
\hline $\begin{array}{l}\text { Cytokines } \\
\text { IL-1B, IL-4, IL-6, IL-8 (CXCL8) } \\
\text { IL-10, IL-12, IL-17A, IL-18, IL-22 [44-51] } \\
\text { MCP-1 (CCL2) [52] } \\
\text { RANTES (CCL5) [53], } \\
\text { GRO- } \alpha \text { (CXCL1) [47], } \\
\text { SDF1 (CXCL12) [54, 55], MIF [56, 57] }\end{array}$ & \multirow{3}{*}{$\begin{array}{l}\text { Mesenchymal stem cells } \\
\text { Oct-4 [82] } \\
\text { Htert, Musashi-1 [84] } \\
\text { CD73 MSC/migration (NT5E) [83] } \\
\text { CD90 MSC/marker of T cells (THY-1) } \\
\text { [81,83,85] } \\
\text { CD105 MSC (ENG) [83, 85] } \\
\text { CD140B (PDGFRB) [81] } \\
\text { CD146 (MCAM) [81] } \\
\text { CD29 MSC/adhesion molecule (ITGB1) [81] } \\
\text { CD44 MSC/hyaluronic acid receptor [81, 83] } \\
\text { CD9 MSC/angiogenesis [83] } \\
\text { CD41a MSC/fibrinogen receptor [83] } \\
\text { ALCAM/CD166 [85] }\end{array}$} & \multirow[t]{3}{*}{$\begin{array}{l}\text { Genome-wide } \\
\text { VEGFR-2 (4q11-q12) [120] } \\
\text { WNT4 (1p36.12) [121] }\end{array}$} \\
\hline $\begin{array}{l}\text { Autoantibodies } \\
\text { IgG anti-laminin-1 [58] } \\
\text { anti-endometrial [59] } \\
\end{array}$ & & \\
\hline $\begin{array}{l}\text { Environment contaminants } \\
\text { dioxin-like chemicals [60] }\end{array}$ & & \\
\hline
\end{tabular}

A secondary Müllerian system development is suggested by another theory launched in 70s [128].

As a result of further studies and epidemiologic characteristics, the hypothesis of transplantation, due to retrograde menstruation $[9,133,134]$, or to mechanical transplantation [9] has been later developed.

In order to find a possible mechanism for implants' development in other locations which could not be ex- 
plained by previous hypotheses, benign lymphogenous or hematogenous metastasis (hystero-adenosis metastatica) $[135,136]$, or combinations of in situ development with endometrial transplantation and implantation or induction theory $[132,137]$ have been later proposed.

\section{Mechanisms and dynamics of endometriosis: current concepts}

Considering the wide distribution of endometriosis locations within human organism, modern theories try to combine the effect of multiple contributors, as multi-factorial, multi-compartmental pathogenic phenomena, associated with epiphenomena, as sequelae of the primary lesions, such as estrogen dependence [138], genetic susceptibility [139], and the possibility of direct spread by "transplantation" [9]. These processes are added to the incapacity of the immune system to neutralize ectopic endometrial cells [140-142], or the contextual environmental factors to intervene in the process, and the occurrence of congenital defects, such as atretic hymen. The last but not the least, the most plausible pathogenic mechanism is the involvement of stem cells as the main "culprits" in the process of ectopic implantation via retrograde menses.

\section{Retrograde menstruation and stem cells: a new perspective of an old theory}

The currently agreed endometriosis pathogenic mechanism is that of retrograde menstruation, via fallopian tubes, a theory that had been launched by Sampson, as early as in 20's. There are numerous elements that plead for the accuracy of this theory, as following: the retrograde menstruation is quite frequent, being estimated that viable endometrial cells may be found in peritoneal cavity in about $76-90 \%$ of women, in non-menstrual periods of time or in peritoneum, during menstruation or immediately after this phase [143]. Furthermore, the blocking of evacuation of the menstrual blood results in extended endometriosis [143]. Moreover, an endometriosis onset at prepuberty is quite rare [143].

The counterarguments of the involvement of this mechanism are provided by evidences that endometriosis may appear in areas which are inaccessible to menstrual reflux, including extra-peritoneal locations, a finding that may support lymphatic or hematogenous cells migration [4].

Relatively recent data have demonstrated the occurrence of mesenchymal stem cells and progenitor endometrial cells in endometriosis and their possible evolution toward differentiation into nine cellular lines: adipocytic, osteogenic, cardiomyocytic, respiratory epithelium, neurocytic, myocytic, endothelial, pancreatic, and hepatic types [144].
Although a key role is attributed to the stem cells reflux into the peritoneal cavity, the microenvironment factors that stimulate stem cells' functions and allow the development of endometriotic implants are very important in the retrograde menstruation mechanism.

\section{Role of metalloproteinases}

MMPs are involved in endometrial turnover and its pathology [145]. In endometriosis, after the attachment to the ectopic sites, the epithelial endometrial cells invade the extracellular matrix. It has been demonstrated that this process occurs with the involvement of MMPs, their high concentration in the peritoneal fluid being stimulated by TNF- $\alpha$ and IL-1 [146]. Concomitantly, TNF- $\alpha$ inhibits TIMP-1 and TIMP-2 [147], resulting in an unbalanced MMPs/ /TIMPs ratio [17, 18, 28, 30, 31]. Increased MT5MMP expression [31] and alterations of the balances between MMP-9/TIMP-1 [30], MMP-9/TIMP-3 [28], MMP-3/uPA [66], VEGF/MMP-3/uPA [68], VEGF/ /MMP-2/CD44/Ki67 [69], PAI/TIMP-1 [70], and IL-1/ /MMP-1 [67] are characteristic features of endometriosis (Table 1).

\section{Inflammation: cells and cytokines}

Another important feature in endometriosis pathogenesis is attributed to the occurrence of pelvic inflammation. Numerous studies have demonstrated that macrophages, lymphocytes, endometrial and mesothelial cells are capable of producing cytokines and inflammatory mediators such as ILs [45-51, 67, 148], TNF- $\alpha[149,150]$, PGF2, PGE2 and thromboxane B2 [151], MCP-1 [52, 152], RANTES [53], eotaxin [153], GROa [47], SDF1 [54, 55], and MIF [56, 57, 152, 154, 155]. These cytokines recruit numerous cellular types, such as macrophages, lymphocytes, eosinophils, mast cells, and endometrial cells into the peritoneal cavity. This process is followed by cascade of events leading to the stimulation of endometriotic cells proliferation, along with their adhesion to ectopic substrates, angiogenesis, and stimulation of the release of other cytokines and chemokines, furthermore amplifying their effects.

Peritoneal macrophages seem to have the highest capability of secreting various types of cytokines and inflammatory mediators. Macrophages amplify the activity of COX-2 and PGE2, which results in VEGF stimulation in endothelial cells of endometriotic implants, together with that of StAR, resulting in an increased estrogen level in the endometrial tissue [23, 156-160]. Estrogens and PGE2 are inducing FGF-9 expression that activates endometrial cells proliferation, in a parallel manner to the stimulation 


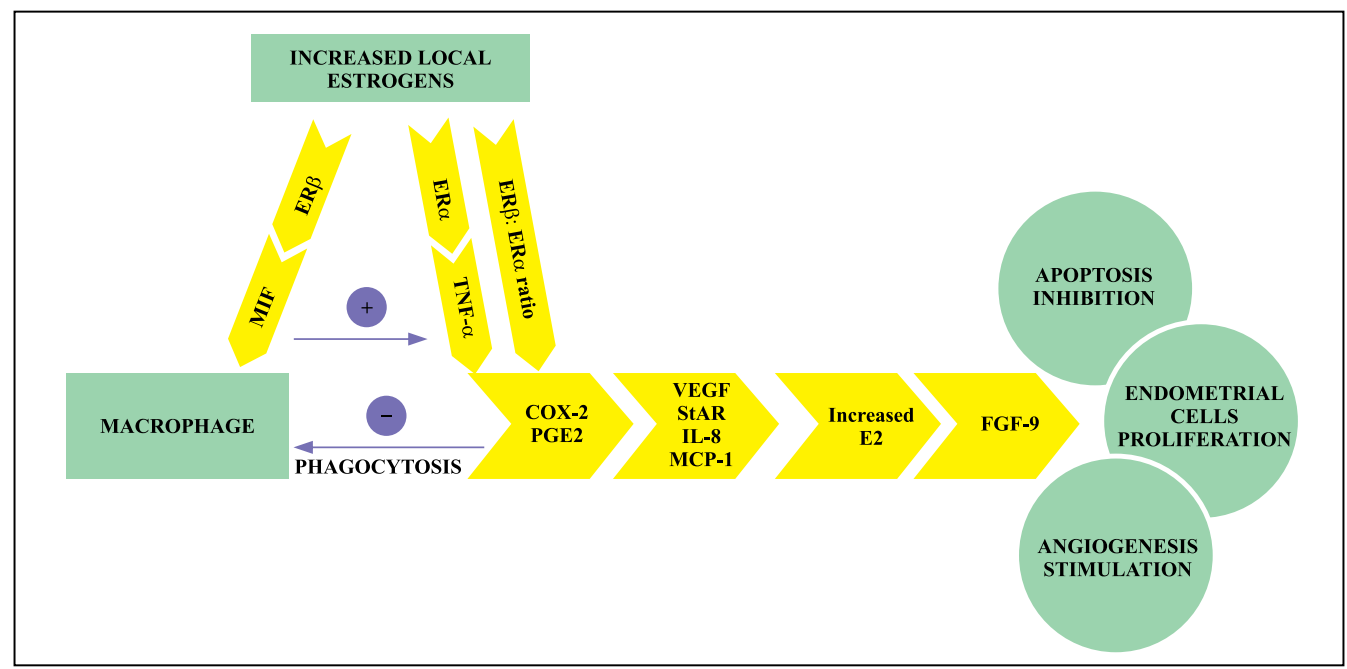

Figure 3. Pivotal role of macrophages in the development of endometriosis results from amplifying the activity of COX-2 and PGE2 production, stimulation of VEGF, StAR, IL-8 and MCP-1 secretion, increased estradiol (E2) level and FGF-9 synthesis, which leads to endometrial cells proliferation, stimulation of angiogenesis, and apoptosis inhibition. MIF, induced by local estrogen reciprocally stimulates TNF- $\alpha$ in endometrial cells. PEG2 acts as an inhibitor of phagocytosis. Furthermore, altered ER expression of estrogen receptors (ER) stimulates the cascade of events. Detailed description in the main text.

of angiogenesis and apoptosis inhibition [23]. PGE2 suppresses the activity of phagocytes, allowing the development of endometriotic implants [23] (Fig. 3).

NK cells have been also incriminated in endometriosis pathogenesis. The hypothesis of an inefficient clearance of the endometrial cells from the peritoneal cavity has been proposed [161,162], due to peripheral and peritoneal NK cells failure to eliminate autologous dendritic cells [163] expressing self-endometrial antigens what results in their presentation to autoreactive $\mathrm{T}$ cells and the production of auto-antibodies [164].

Lymphocytes are also involved in various cytokines production with potential role in endometriosis development. Peritoneal fluid Th2 cells were shown to stimulate the secretion of IL-4 and IL-10, mainly by peritoneal macrophages, resulting in an aberrant suppression of cell-mediated immunity what may enable implantation of endometrial cells in peritoneum [165].

Moreover, the NK cell-mediated cytotoxicity, manifested by lymphocytes adherence to endometrial cells by LFA-1 - ICAM-1 pathway and their presentation as targets to NK cells, may fail in endometriosis. This finding has been demonstrated by an in vitro study [166] and later on confirmed by flow cytometry in human endometriosis [167]. According to this possible mechanism involved in endometriosis pathogenesis, sICAM-1 may bind to LFA-1 expressing lymphocytes, preventing endometrial cells recognition by lymphocytes and, fur- thermore, preventing NK-mediated cytotoxicity [166]. Consequently, endometriosis is characterized by the inability of immune cells to send death signals to endometrial cells and/or the ability of ectopic endometrial fragments to avoid cellular death due to an increased expression of anti-apoptotic molecules [168].

TNF- $\alpha$, a pro-inflammatory cytokine, is also produced by macrophages, exhibiting elevated levels in the peritoneal fluid [36, 169] and serum [169] in endometriosis patients. It has been shown recently that TNF- $\alpha$-induced IKK $\beta$ complex activation leads to the initiation and progression of endometriosis, by enhancing the viability of the ectopic epithelial cells but not eutopic epithelial cells, or endometrial stromal cells [170].

MIF, another cytokine, shows a high level in the peritoneal fluid, in circulation, and in peritoneal macrophages, its secretion being induced in endometriosis by estrogens [171]. MIF stimulates endothelial cell proliferation, endometriotic lesion survival, expression of PGE2, COX-2, VEGF, IL-8, MCP-1, aromatase, and reciprocally stimulates TNF- $\alpha$ in endometrial cells [56, 152, 158, 172]. ISO-1, MIF antagonist, is responsible for a significant reduction in endometriotic lesion size, in experimental models, by inhibiting cell adhesion, tissue remodeling, angiogenesis, and inflammation, in addition to alteration of the balance between pro- and anti-apoptotic factors [155]. 


\section{Hormones and hormone-like substances in the pathogenesis of endometriosis}

Steroid hormones play an important role in endometrial physiology and their unbalanced activity is involved in endometrial pathology, including endometriosis.

In this regard, it has been demonstrated that the driving factor of the production of cytokines in endometriosis is the altered responsiveness to progesterone, showing a characteristic very low expression of progesterone receptor $\mathrm{A}$ (PR-A) and the absence of PR-B in mice models [173], and in a similar way with decreased PR-B/A ratio and reduced PR-B immunoreactivity, demonstrated in human endometriosis [78, 174].

Supplementary, the increased local estrogen levels further drive the endometriotic lesion phenotype and increased cytokine expression and apoptosis in a murine endometrium [175]. Hormonal dependence in endometriosis is demonstrated by an increased ER- $\beta$ expression (approximately 100 times more than that of eutopic endometrium), due to altered methylation in the ESR2 gene promoter [174]. ER- $\beta$ overexpression suppresses ER- $\alpha$ expression and, furthermore, leads to an abnormally high ER- $\beta /$ ER- $\alpha$ ratio, which is responsible to a reduced expression of $\mathrm{PR}$ and an increased COX-2 expression [38, 39, 77, 171]. ER- $\beta$ activation results in the stimulation of MIF expression and production in the cultures of human endometrial cells [171]. In experimental endometriosis model, ER- $\beta$ seems to be responsible for the inhibition of endometriotic cell apoptosis and the increased cytokine production, such as MCP-5, IL-1 $\beta$, and IL-16, which results in enhanced cell adhesion and proliferation [175].

Stimulation of COX-2 activity by MIF results in the increased secretion of PGE2 that is considered a master regulator of endometriosis on the basis of its pro-inflammatory actions documented by its elevated levels in human endometriotic tissue and in peritoneal fluid $[158,176]$.

\section{Angiogenesis in endometrial tissue}

The angiogenic activity is stimulated in endometriosis by a large spectrum of angiogenic factors such as IL-1 [177], IL-6, IL-8, VEGF [178], ENDO-I (an endometrial haptoglobin homologue) [179], angiogenin [180], pleiotrophin, midkine [181], TNF- $\alpha$ [182], PGF [183], angiopoietin [25], and glycodelin [26, 27]. Moreover, in endometriosis the physiological angiogenic activity is supplemented by the co-existence of pathologic angiogenesis, immune suppression, and immune activation [184]. Environmental factors, such as dioxins, may be also responsible for an increased angiogenesis [60].
VEGF-A role is demonstrated by its increased concentrations in serum, peritoneal fluid, and endometrium of patients with endometriosis $[17,185,186]$. For instance, it was found that high levels of serum VEGF-A are useful for the diagnosis and follow-up in advanced stage of endometriosis [17]. Moreover, it was confirmed that the expression of $V E G F-A$ gene was higher in peritoneal endometriosis compared with normal peritoneum [185].

One of the tools to assess angiogenesis in endometriosis is the measurement of vascular surface density (microvessel density or mean vascular density, MVD) [187]. An in vivo study, using transvaginal color and power Doppler, has demonstrated the correlation between high MVD and pelvic pain in patients with endometriosis [188]. This finding has been validated by immunohistochemical evaluation of CD34-labeled vessels [24, 188]. Although the active lesions showed a high mitotic index and increased MVD in implants, no significantly increased VEGF expression has been found, suggesting the involvement of other angiogenic factors [24].

\section{Apoptosis}

An apoptosis evasion mechanism has been demonstrated in endometriosis, allowing the development of ectopic implants. This particular mechanism has been characterized by increased expression of anti-apoptotic Bcl-2 along with decreased pro-apoptotic Bax expression [99, 100]. Apoptosis may be also regulated by Fas ligand (FasL) by its binding to cell membrane receptor, Fas. FasL binding results in extrinsic (autocrine or paracrine) induction of apoptosis [189]. It was found that in cultured human endometrial stromal cells IL-8 up-regulated FasL protein expression and decreased apoptosis rate [189], the latter found in human endometrial tissue was associated with increased mRNA levels of survivin and MMPs [101].

\section{Multistep development of endometriosis}

The results of numerous studies in humans and in animal models allowed proposing a multistep etiopathogenic mechanism of endometriosis [50, 190-197].

Following retrograde menstruation which is the triggering phenomena responsible for an increased number of endometrial cells in peritoneal fluid, other associated mechanisms are contributing to immune surveillance failure (i.e. decreased NK cytolytic [46] and cytotoxic $[162,198]$ activity, ICAM-1 secretion [35]), that is further supplemented by decreased apoptosis of endometriotic cells $[175,199]$. The next stage is marked by the localization of refluxed endometrial cells in the peritoneal cavity, followed by increased number of activated macrophages, increased secretion 
of proinflammatory cytokines, such as IL- $1 \beta$, IL-6, IL-8, IL-12, IL-17A, IL-18, IL-22 [44-52] and TNF- $\alpha$ $[42,146,170]$, chemokines (e.g. MCP-1 [42, 52] and RANTES [53, 200]), and growth factors, such as EGF, FGF-9, TGF- $\beta$, and HGF [20-23]. The following step is the adherence of ectopic endometrium, followed by implantation and invasion, being associated with the stimulation of TGF- $\beta$, IL-1, TNF- $\alpha$, along with MMPs and TIMPs secretion [28-31, 42, 50, 201, 202].

After the ectopic implantation and invasion, other processes take place: stimulation of angiogenesis due to enhanced levels of IL-1, IL-6, and VEGF, decreased immune surveillance, increased presentation of self-antigens by dendritic cells, $\mathrm{T}$ and $\mathrm{B}$ cells activation, elevated levels of autoantibodies, and positive feedback enhancing inflammation and immune responses [141].

These cascading events are responsible by the continuous development and persistence of endometriosis. The available evidence strongly suggests that pivotal factors can be attributed to cytokines and growth factors produced by activated macrophages which not only fail to eliminate but promote development of endometriosis.

\section{Endometriosis versus carcinogenesis}

\section{Relationships between endometriosis and malignancy}

As early as in 1927, the idea linking endometriosis with malignant transformation has been hypothesized [203], mainly for the ovarian location. Since then, numerous studies have demonstrated the overlap of definition criteria of malignant phenotype with those of endometriosis. Results of meta-analyses revealed their increased association [204, 205].

Clinicopathological, molecular, and genetic evidences support the hypothesis of endometriosis as a neoplastic process, with a potential to malignant transformation. The first evidence is that of the common features shared by these entities that are both able to disseminate, to invade, and to form distant implants [206]. Moreover, a significant association of endometriosis with clear cell and endometrioid ovarian carcinomas has been reported [87, 95, 103, 104, 106, 207-211], e.g. 30-55\% and 30-40\%, respectively [206]. Furthermore, an increased incidence of concurrent primary malignancy, i.e. endometrial carcinoma, in endometriosis-associated ovarian malignancies suggests common molecular pathways in both locations [212]. A plethora of phenomena are common in sporadic cancer and endometriosis, being determined by complex interactions between hereditary polygenic alleles of low penetrance (polymorphism), acquired genetic alterations, leading to a "signature" of mutations, and microenvironment "permissive" factors, expressed by hormonal influences and chronic inflammation [44, 210, 212]. The current molecular techniques of genetic, transcriptomic and proteomic profiling allow for better characterization of correlations between genetic and local milieu alterations and transition process from normal endometrium to malignant transformation.

A large spectrum of tumors and tumor-like conditions associated with endometriosis has been described, such as polypoid endometriosis, benign tumors (such as endometrioid adenoma, adenofibroma, cystadenofibroma, and cystadenoma), premalignant changes (i.e. atypical endometriosis) (Fig. 1C), borderline tumors (e.g. endometrioid cystic adenofibroma and endometrioid cystadenofibroma), and malignant tumors, such as endometrioid adenocarcinoma (Fig. 1D), with squamous elements or with clear cell elements, low-grade and high-grade stromal sarcoma, and malignant tumors with mixed components (i.e. adenosarcoma and carcinosarcoma) [109, 206, 212-215].

Another criterion in favor of a relationship between endometriosis and malignancies is that endometriosis consists of a monoclonal tissue development, acquiring many of the cellular characteristics of malignant transformation [4]. Furthermore, the analysis of common features of endometriosis and tumors has revealed that endometriosis can be regarded as an estrogen-dependent neoplasm with an estrogen-induced signaling mechanism characterized by increased production of estrogens [38, 39], increased P450 cytochrome aromatase activity [171], increased activity of StAR [156], increased PGE2 production $[156,158]$, increased estrogen responsivity by ER- $\beta$ overexpression, decreased ER- $\alpha$ expression and abnormal high ER- $\beta$ : ER- $\alpha$ ratio [76, 77], decreased expression and responsivity of PR [78], and hereditary genetic polymorphism of drug-metabolizing enzymes [216, 217].

It is also widely recognized that in both endometriosis and cancer, there is co-existence of pathologic angiogenesis [218]. Importantly, an increased MMPs expression associated to deregulation of the intercellular adherence signaling is identified both in endometriosis pathogeny and in carcinogenesis.

The current knowledge is that two pathways seem to be involved in endometriosis and its potential progression toward neoplasia: either malignant transformation, probably by an atypical transition stage, either the common precursor mechanism or predisposing factors are shared by both processes, with a consecutive molecular divergence [219]. Relatively 
recent histopathological data confirm the possibility of transition due to identification of an atypical stage and frequent association of ovarian cancer to atypical endometriosis. The significance of borderline tumors is currently regarded as a part of endometriosis-associated ovarian carcinoma spectrum [206, 214, 215]. Moreover, recent evidences indicate that patients with endometriosis have a significant risk for endometrial cancer, mainly endometrioid and clear cell subtypes [220].

\section{Endometriosis as a precursor lesion}

In endometriosis pathogenesis, an important role has to be attributed to polygenic susceptibility, which implies a metabolic, endocrine, and immune associations, responsible for the increase of the number of endometrial cells and/or immune surveillance decrease and by specific qualities of endometrial cells from the peritoneal fluid and/or pelvic inflammation [221-223]. Furthermore, the progressive accumulations of genetic alterations of tumor-suppressing genes and oncogenes are probably responsible for endometriosis development and its possible association with the development of malignancies [87-89, $92,107,224,225]$.

In numerous studies it was shown that the genetic polymorphism is predisposing either to endometriosis (e.g. of ICAM-1 or gene promoters of IL-6 and IL-10), or to cancer (of genes encoding IL-6, IL-8, TNF- $\alpha$, NF $\kappa$ B-1, and PPAR- $\gamma$ ) [52, 216, 225, 226]. Moreover, the processes involved in endometriosis development are supplemented by genomic instability which contributes to the transition to the stage of atypical endometriosis. Mutations of genes linked to carcinogenesis have been also identified in endometriosis, such as alterations of tumor suppression genes [87-98], inactivation of DNA mismatch repair genes, by hypermethylation [93], and $\mathrm{LOH}[87,107$, 109, 219]. Thus, the next step represented by a transition or pre-malignant phase, is characterized by $4 \mathrm{q}$, 5q, 6q, 9p, 11q, 22q, 10q23.3, 17p13.1 LOH [87, 107, $109,219]$, inactivating mutation of PTEN [87-89, 93, 227, 228], loss of TP53 [90, 91, 107, 228, 229], mutations located at multiple loci of beta-catenin, and cadherin switch [34, 71, 73, 104], contributing to the development of endometrioid and clear cell ovarian carcinoma [227-229]. Furthermore, somatic mutations in TSG germinal lines may add support to this hypothesis [107, 224, 225].

Considering the panel of genetic mechanisms which act synergistically contributing to cancer genomic instability, with variable overlapping contribution, such as oncogenic activity, TSG inactivation, DNA repairing enzymes anomalies, inactivation of checkpoints genes of cellular cycle assembly, and telomere dysfunctions, some of these pathways have to be also detected in precursor lesions. As expected, premalignant lesions (atypical endometriosis) are characterized by several mutations of tumor suppressor genes, oncogenes, CAMs, and furthermore $\mathrm{LOH}$ and inflammatory immunomodulation [198]. Table 2 summarizes the arguments in favor of a common genotype in endometriosis and endometriosis-associated ovarian cancers.

\section{Novel approaches and therapeutic agents in endometriosis}

Acknowledging the role of hormonal stimulation in endometriosis, a panel of drugs has been developed to modulate the excessive ovarian estrogens synthesis, e.g. oral contraceptives (containing an estrogen component, such as ethinyloestradiol, mestranol, estradiol or its pro-drug estradiol valerate, combined with a progestogen, such as levonorgestrel, norethisterone, drospirenone, gestodene, desogestrel, nomegestrol, dienogest or cyproterone) [248], gestagens [249], and danazol ((17a)-Pregna-2,4-dien-20-yno[2,3-d] isoxazol-17-ol) [19]. Danazol has hormonal action, by antigonadotropic action, androgenic activity, and interaction with ERs and is also considered a powerful immunologic tool in endometriosis, due to its ability to decrease immunoglobulins, $\mathrm{C} 3$ and $\mathrm{C} 4$ complement, auto-antibodies against phospholipid antigens, and CA-125 levels, as well as its capacity to suppress lymphocyte proliferation, along with suppression of IL-1 and TNF- $\alpha$ production by macrophages [19].

The analysis of the common characteristics of carcinogenesis and endometriosis development, such as sustained proliferative capacity, evasion of growth suppressors and of immune destruction, replicative immortality, involvement of tumor-promoting inflammation, angiogenesis, invasion and metastasis, genome instability and mutations, resistance to cell death stimuli, and deregulation of cellular energetics, lead to the enlargement of the therapeutic arsenal by targeting common molecules and molecular pathways involved in endometriosis and endometriosis-related ovarian cancers [96, 102, 208, 230, 250-256].

Thus, by comparing the similar molecular pathways identified in both endometriosis and other cancers (i.e. breast, ovary, and endometrium cancers), a series of anti-cancer agents are currently in different clinical trials for endometriosis therapy, awaiting their validation. Table 3 documents the progress achieved in endometriosis by therapy with anti-cancer agents [102, 201, 208, 230-233, 250-259]. Novel therapeutic approaches applicable in endometriosis show at least five categories of anti-cancer agents that may relate 
Table 2. Common molecular features in endometriosis and ovarian cancer

\begin{tabular}{|c|c|c|c|}
\hline Role & Pathway/Molecule & Endometriosis & $\begin{array}{l}\text { Endometriosis — associated } \\
\text { ovarian cancers }\end{array}$ \\
\hline \multirow[t]{4}{*}{ Tumor suppressor } & $\begin{array}{l}\text { ARID1A } \pm \text { BAF250a mutation } \\
{[94,95,96,105,209,230-233]}\end{array}$ & $\begin{array}{l}\text { expressed } \\
{[105,233]}\end{array}$ & $\begin{array}{l}\text { expressed } \\
{[94,95,96,105,209,230-232]}\end{array}$ \\
\hline & $\begin{array}{l}\text { PTEN somatic mutations } \\
{[87-89,93,227,228,234]}\end{array}$ & $\begin{array}{l}\text { expressed } \\
{[88,89,93,227,228]}\end{array}$ & $\begin{array}{l}\text { expressed } \\
{[87,88,227,228,234]}\end{array}$ \\
\hline & $\begin{array}{l}\text { PIK3CA mutations } \\
{[96,104,207]}\end{array}$ & $\begin{array}{l}\text { early event in endometriosis } \\
\text { transformation [104] }\end{array}$ & $\begin{array}{l}\text { expressed } \\
{[96,104,207]}\end{array}$ \\
\hline & $\begin{array}{l}\text { ТР53 } \\
{[90-92,107,213,228,229]}\end{array}$ & $\begin{array}{l}\text { expressed } \\
\text { (late stages) } \\
{[91,92,107,228]}\end{array}$ & $\begin{array}{l}\text { expressed } \\
\text { (advanced stages) } \\
{[90,213,228,229]}\end{array}$ \\
\hline \multirow[t]{2}{*}{ Oncogene } & $\begin{array}{l}\text { KRAS } \pm \text { BRAF } \\
{[103,235]}\end{array}$ & $\begin{array}{l}\text { expressed } \\
\text { (atypical endometriosis) } \\
{[103,235]}\end{array}$ & $\begin{array}{l}\text { expressed } \\
\text { (mucinous type) } \\
{[103]}\end{array}$ \\
\hline & $\begin{array}{l}\text { CTNNB1/WNT/ } \beta \text {-catenin } \\
{[72,227,236,237]}\end{array}$ & $\begin{array}{l}\text { expressed } \\
\text { (atypical endometriosis) } \\
{[72,237]}\end{array}$ & $\begin{array}{l}\text { expressed } \\
{[227,236]}\end{array}$ \\
\hline miRNA profiling & $\begin{array}{l}\text { miRNA instability } \\
{[238-244]}\end{array}$ & $\begin{array}{l}\operatorname{miR}-9 \\
{[238-244]}\end{array}$ & $\begin{array}{l}\text { absent } \\
{[238]}\end{array}$ \\
\hline Microsatellite instability & BRCA1/2 [245] & $\begin{array}{l}\text { absent } \\
-\end{array}$ & $\begin{array}{l}\text { expressed } \\
{[245]}\end{array}$ \\
\hline \multirow[t]{2}{*}{$\mathrm{LOH}$} & 9p, 11q, 22q [246] & $\begin{array}{l}\text { expressed } \\
{[246]}\end{array}$ & $\begin{array}{l}\text { absent } \\
-\end{array}$ \\
\hline & $10 q 23$ [109] & $\begin{array}{l}\text { expressed } \\
\text { (atypical endometriosis) } \\
{[109]}\end{array}$ & $\begin{array}{l}\text { expressed } \\
{[109]}\end{array}$ \\
\hline Immunomodulation & $\begin{array}{l}\text { complement pathways } \\
\text { [247] }\end{array}$ & $\begin{array}{l}\text { expressed } \\
{[247]}\end{array}$ & $\begin{array}{l}\text { expressed } \\
{[247]}\end{array}$ \\
\hline
\end{tabular}

their main action to hormonal substrate, angiogenesis, apoptosis, cellular cycle, and immune status.

Hormonal status is addressed by administration of aromatase inhibitors (letrozole, anastrozole) which block the conversion of androstendione to estrone, creating a low estrogen environment [260]. Another approach is to modulate ER activity, either by ER- $\beta$ ligands (CLI or OBHS) already used in clinical practice [261] or by selective ER modulators (arzoxifene, bazedoxifene [262], raloxifene [263]) which are still tested in experimental models. In the regulation of progesterone action, $\mathrm{P} 4$ antagonists (mifepristone, RU-486 [264]) and selective PR modulators (asoprisnil, BAY 1002670) [265], PF-02413873 [266]) have shown promising results in endometriosis therapy in either clinical application or in rodent experiments. In order to eliminate the systemic side effects, Mirena coil (levonorgestrel-releasing intrauterine system) has been added to the therapy [267]. In an attempt to regulate the hypothalamic stimulation of the hormonal axis, Gn-RH agonists (elagolix [268], leuprolide, nafarelin, buserelin, goserelin, triptorelin [269], abarelix [270]) showed regression of human endometriotic lesions related to hypoestrogenism and, possibly, to a supplementary anti-angiogenic activity.

Anti-angiogenesis has been considered as an alternative therapeutic approach showing efficacy in endometriosis reduction without side effects on fertility or toxicity profiles. Several anti-angiogenic agents have been tested in experimental endometriosis. In mouse models, rapamycin clearly reduced endometriotic implants, along with diminished VEGF expression and decreased MVD [271]; in the nude mouse model endostatin affected expression of VEGFR2 and/or VEGF isoforms and decreased HIF- $1 \alpha$ expression [272], while angiostatin showed a complex mechanism of the inhibition of blood vessel development [273, 274]; anginex demonstrated anti-angiogenic activity in mouse model of endometriosis [274]. In a rat endometriosis model, bevacizumab, VEGF-neutralizing monoclonal antibody, was shown to increase apoptosis [275]. Other drugs with anti-angiogenic effects confirmed in experimental endometriosis are celecoxib, a COX-2 inhibitor [276], and non-toxic fumagillin analogs, semisynthetic derivatives of a natural antibiotic, Aspergillus fumigatus [274]. The results of these 
Table 3. Targeted therapy in endometriosis and endometriosis-associated ovarian malignancies

\begin{tabular}{|c|c|c|c|}
\hline Molecules and pathways & Effect & Therapeutic agent & Targeted action \\
\hline $\begin{array}{l}\text { JAK/STAT } \\
{[259]}\end{array}$ & Cell proliferation & $\begin{array}{l}\text { Leflunomide } \\
\text { Atiprimod }\end{array}$ & $\begin{array}{l}\text { JAK inhibitor } \\
\text { STAT3 inhibitor }\end{array}$ \\
\hline $\begin{array}{l}\text { TGF- } \beta / \text { SMAD } \\
{[201]}\end{array}$ & $\begin{array}{l}\text { Dual roles in regulation cell } \\
\text { proliferation (balance of } \\
\text { pro-proliferative and anti-proli- } \\
\text { ferative effects) }\end{array}$ & $\begin{array}{l}\text { Lerdelimumab } \\
\text { Metelimumab } \\
\text { GC-1008 } \\
\text { SD-093 } \\
\text { LY-580276 }\end{array}$ & $\begin{array}{l}\text { Recombinant human IgG4 } \\
\text { targeting TGF- } \beta 2 \\
\text { Recombinant human IgG4 } \\
\text { targeting TGF- } \beta 1 \\
\text { Targets all TGF- } \beta \text { isoforms } \\
\text { Small molecule inhibitors of } \\
\text { SMAD } 2 / 3 \text { activity }\end{array}$ \\
\hline $\begin{array}{l}\text { MEK/ERK } \\
{[260]}\end{array}$ & $\begin{array}{l}\text { Regulation of signaling for pro- } \\
\text { liferation, apoptosis, adhesion, } \\
\text { invasion, angiogenesis, and } \\
\text { evasion of immune surveillance }\end{array}$ & Selumetinib & $\begin{array}{l}\text { Small molecular inhibitor of } \\
\text { MEK }\end{array}$ \\
\hline \multirow[t]{2}{*}{$\begin{array}{l}\text { VEGF } \\
{[251,252,256]}\end{array}$} & \multirow[t]{2}{*}{ Growth of tumor vessels } & Bevacizumab & $\begin{array}{l}\text { Inhibits receptor binding and } \\
\text { prevent tumor angiogenesis }\end{array}$ \\
\hline & & Sunitinib & $\begin{array}{l}\text { Multitargeted receptor tyrosine } \\
\text { kinase inhibitor (VEGFR, } \\
\text { PDGFR, CD117) }\end{array}$ \\
\hline \multirow{2}{*}{$\begin{array}{l}\mathrm{PI} 3 \mathrm{~K} / \mathrm{AKT} / \mathrm{mTOR} \text { signaling } \\
\text { pathway }[250]\end{array}$} & \multirow{2}{*}{$\begin{array}{l}\text { Lipid kinases that regulate vital } \\
\text { signaling pathways in neoplasia }\end{array}$} & RAD001 & mTOR inhibitor \\
\hline & & Temsirolimus & mTOR inhibitor \\
\hline $\begin{array}{l}\text { AnxA4 } \\
{[255,261]}\end{array}$ & $\begin{array}{l}\text { Exocytosis and regulation of } \\
\text { epithelial } \mathrm{Cl}^{-} \text {secretion }\end{array}$ & AnxA4-neutralizing antibodies & AnxA4 blockade \\
\hline $\begin{array}{l}\text { ARID1A } \\
{[230-233]}\end{array}$ & $\begin{array}{l}\text { AT-rich interactive domain 1A } \\
\text { (SWI-like) gene encodes } \\
\text { BAF250A (member of the } \\
\text { SWI/SNF ATP-dependent } \\
\text { chromatin remodeling } \\
\text { complex) }\end{array}$ & $\mathrm{EZH} 2$ & $\begin{array}{l}\text { EZH2 inhibition upregulates } \\
\text { PI3K which negatively } \\
\text { regulates PI3K/AKT signals }\end{array}$ \\
\hline $\begin{array}{l}\text { HNF-1 } \beta \\
{[102,208]}\end{array}$ & $\begin{array}{l}\text { Transcription activator expres- } \\
\text { sed also in endometriosis which } \\
\text { regulates multiple cancer-rela- } \\
\text { ted genes }\end{array}$ & $\begin{array}{l}\text { Future inhibitors/inhibitors of } \\
\text { genes activated by HNF-1 } \beta\end{array}$ & $\begin{array}{l}\text { HNF-1 } \beta \text { inhibitor } \\
\text { dipeptidyl peptidase IV inhi- } \\
\text { bitor, osteopontin inhibitor, } \\
\text { tissue factor pathway inhibi- } \\
\text { tor } 2 \text {, AnxA4 inhibitor, and } \\
\text { angiotensin-converting enzyme } \\
2 \text { inhibitor }\end{array}$ \\
\hline $\begin{array}{l}\text { ZNF217 } \\
{[253,254]}\end{array}$ & $\begin{array}{l}\text { Gene situated on } 20 \mathrm{q} 13.2 \\
\text { encoding a transcription factor } \\
\text { in cancers associated with poor } \\
\text { prognosis and lymph node } \\
\text { metastasis }\end{array}$ & Triciribine & $\begin{array}{l}\text { Inhibitor of ZNF127-ove- } \\
\text { rexpressing cells growth }\end{array}$ \\
\hline
\end{tabular}

experimental studies represent provide hope for the application of anti-angiogenic therapies in human endometriosis. Promising novel anti-endometriosis drugs are represented by the pro-apoptotic agents, such as apoptosis inducer (arcyriaflavin) [277], apigenin [278], NF- $\kappa$ B inhibitor (PDTC), and proteasome inhibitors (bortezomib) [279] that were tested on human cell lines and rat models.

\section{Final remarks}

Due to endometriosis heterogeneity, attributed to genomic and proteomic variability, expressed by var- iable anatomic location, number, size and duration of implants, carcinogenesis associations, numerous subtypes of endometriosis have been described.

Current trends in genomic and proteomic approaches are useful for a deeper understanding of endometriosis pathogeny and its malignant transformation, a better (re)classification, and a higher potential identification of new therapeutic targets. The putative biomarkers such as P450 aromatase, IL-6, TNF- $\alpha$, and anti-endometrial cells autoantibodies have been proposed.

Nowadays, the therapy is limited by high frequency of recurrences and the impossibility to preserve 
fertility mainly in women who require extensive surgical procedures. Based on molecular analogies between endometriosis and carcinogenesis, numerous studies are ongoing, being currently during variable experimental phases or in clinical trials, as attempts to exploit the therapeutic anti-cancer arsenal in the treatment of endometriosis.

\section{Conflict of interest}

The authors declare that they have no conflict of interests.

\section{References}

1. Von Ro. Ueber Uterusdrtisen-Neubildung in Uterus- und Ovarial-Sarcomen. Ztsch KK Gesellsch der Aerzte zu Wien. 1860; 37: 577-581.

2. Cullen TS. Adeno-myoma uteri diffusum benignum. Bull Johns Hopkins Hosp. 1896; 6: 133-137.

3. Cullen TS. Adeno-myoma of the round ligament. Bull Johns Hopkins Hosp. 1896; 7: 112-114.

4. Machairiotis N, Stylianaki A, Dryllis G, et al. Extrapelvic endometriosis: a rare entity or an under diagnosed condition? Diagn Pathol. 2013; 8: 194, doi: 10.1186/1746-1596-8-194, indexed in Pubmed: 24294950.

5. De Ceglie A, Bilardi C, Blanchi S, et al. Acute small bowel obstruction caused by endometriosis: a case report and review of the literature. World J Gastroenterol. 2008; 14(21): 3430-3434, indexed in Pubmed: 18528943.

6. Insilla AC. Deep endometriosis with pericolic lymph node involvement: A case report and literature review. World Journal of Gastroenterology. 2014; 20(21): 6675, doi: 10.3748/ /wjg.v20.i21.6675.

7. Fluegen G, Jankowiak F, Zacarias Foehrding L, et al. Intrahepatic endometriosis as differential diagnosis: case report and literature review. World J Gastroenterol. 2013; 19(29): 4818-4822, doi: 10.3748/wjg.v19.i29.4818, indexed in Pubmed: 23922482.

8. Jablonski C, Alifano M, Regnard JF, et al. Pneumoperitoneum associated with catamenial pneumothorax in women with thoracic endometriosis. Fertil Steril. 2009; 91(3): 930. e19-930.e22, doi: 10.1016/j.fertnstert.2008.09.071, indexed in Pubmed: 18976993.

9. van der Linden PJ, van der Linden PJ. Theories on the pathogenesis of endometriosis. Hum Reprod. 1996; 11 Suppl 3: 53-65, indexed in Pubmed: 9147102.

10. Cheng $\mathrm{CH}$, Kuo HC, Su B. Endometriosis in a kidney with focal xanthogranulomatous pyelonephritis and a perinephric abscess. BMC Res Notes. 2015; 8: 591, doi: 10.1186/s13104-015-1574-1, indexed in Pubmed: 26490542.

11. Zamurovic M. Rare extrapelvic endometriosis on iliac vein wall--diagnosis and treatment. Clin Exp Obstet Gynecol. 2014; 41(3): 349-350, indexed in Pubmed: 24992793.

12. Albutt K, Glass C, Odom S, et al. Endometriosis within a left-sided inguinal hernia sac. J Surg Case Rep. 2014; 2014(5), doi: 10.1093/jscr/rju046, indexed in Pubmed: 24876515.

13. Vang R, Wheeler J. Diseases of the Fallopian Tube and Paratubal Region. Blaustein's Pathology of the Female Genital Tract. 2011: 529-578, doi: 10.1007/978-1-4419-0489-8_11.

14. Brătilă E, Brătilă CP, Comandaşu DE, et al. The assessment of immunohistochemical profile of endometriosis implants, a practical method to appreciate the aggressiveness and recur- rence risk of endometriosis. Rom J Morphol Embryol. 2015; 56(4): 1301-1307, indexed in Pubmed: 26743275.

15. Koike N, Tsunemi T, Uekuri C, et al. Pathogenesis and malignant transformation of adenomyosis (review). Oncol Rep. 2013; 29(3): 861-867, doi: 10.3892/or.2012.2184, indexed in Pubmed: 23242072.

16. Pittaway DE, Douglas JW. Serum CA-125 in women with endometriosis and chronic pelvic pain. Fertil Steril. 1989; 51(1): 68-70, indexed in Pubmed: 2910718.

17. Mohamed ML, El Behery MM, Mansour SAA. Comparative study between VEGF-A and CA-125 in diagnosis and follow-up of advanced endometriosis after conservative laparoscopic surgery. Arch Gynecol Obstet. 2013; 287(1): 77-82, doi: 10.1007/s00404-012-2539-4, indexed in Pubmed: 22930151.

18. Harada T, Kubota T, Aso T. Usefulness of CA19-9 versus CA125 for the diagnosis of endometriosis. Fertil Steril. 2002; 78(4): 733-739, indexed in Pubmed: 12372448.

19. Szubert M, Suzin J, Duechler M, et al. Evaluation of selected angiogenic and inflammatory markers in endometriosis before and after danazol treatment. Reprod Fertil Dev. 2014; 26(3): 414-420, doi: 10.1071/RD12258, indexed in Pubmed: 23544741.

20. Ferrero S, Matalliotakis IM, Goumenou AG, et al. Serum concentrations of growth factors in women with and without endometriosis: the action of anti-endometriosis medicines. Int Immunopharmacol. 2003; 3(1): 81-89, indexed in Pubmed: 12538037.

21. Pizzo A, Salmeri F, Ardita F, et al. Behaviour of Cytokine Levels in Serum and Peritoneal Fluid of Women with Endometriosis. Gynecologic and Obstetric Investigation. 2003; 54(2): 82-87, doi: 10.1159/000067717.

22. Zong Ll, Li Yl, Ha Xq. Determination of HGF concentration in serum and peritoneal fluid in women with endometriosis. Di Yi Jun Yi Da Xue Xue Bao. 2003; 23(8): 757-760, indexed in Pubmed: 12919890.

23. Chuang PC, Sun HS, Chen TM, et al. Prostaglandin E2 induces fibroblast growth factor 9 via EP3-dependent protein kinase Cdelta and Elk-1 signaling. Mol Cell Biol. 2006; 26(22): 8281-8292, doi: 10.1128/MCB.00941-06, indexed in Pubmed: 16982695.

24. García-Manero M, Santana GT, Alcázar JL. Relationship between microvascular density and expression of vascular endothelial growth factor in patients with ovarian endometriosis. J Womens Health (Larchmt). 2008; 17(5): 777-782, doi: 10.1089/jwh.2007.0695, indexed in Pubmed: 18479230.

25. Hur SE, Lee JiY, Moon HS, et al. Angiopoietin-1, angiopoietin-2 and Tie-2 expression in eutopic endometrium in advanced endometriosis. Mol Hum Reprod. 2006; 12(7): 421-426, doi: 10.1093/molehr/gal049, indexed in Pubmed: 16723371.

26. Drosdzol-Cop A, Skrzypulec-Plinta V. Selected cytokines and glycodelin A levels in serum and peritoneal fluid in girls with endometriosis. J Obstet Gynaecol Res. 2012; 38(10): 1245-1253, doi: 10.1111/j.1447-0756.2012.01860.x, indexed in Pubmed: 22563871.

27. Kocbek V, Vouk K, Mueller MD, et al. Elevated glycodelin-A concentrations in serum and peritoneal fluid of women with ovarian endometriosis. Gynecol Endocrinol. 2013; 29(5): 455-459, doi: 10.3109/09513590.2013.769516, indexed in Pubmed: 23461865.

28. Chung HW, Wen Y, Chun SH, et al. Matrix metalloproteinase- 9 and tissue inhibitor of metalloproteinase-3 mRNA expression in ectopic and eutopic endometrium in women with endometriosis: a rationale for endometriotic invasive- 
ness. Fertil Steril. 2001; 75(1): 152-159, indexed in Pubmed: 11163831.

29. Chung HW, Lee JiY, Moon HS, et al. Matrix metalloproteinase-2, membranous type 1 matrix metalloproteinase, and tissue inhibitor of metalloproteinase-2 expression in ectopic and eutopic endometrium. Fertil Steril. 2002; 78(4): 787-795, indexed in Pubmed: 12372458.

30. Szamatowicz J, Laudański P, Tomaszewska I. Matrix metalloproteinase- 9 and tissue inhibitor of matrix metalloproteinase-1: a possible role in the pathogenesis of endometriosis. Hum Reprod. 2002; 17(2): 284-288, indexed in Pubmed: 11821264.

31. Gaetje R, Holtrich U, Engels K, et al. Expression of membrane-type 5 matrix metalloproteinase in human endometrium and endometriosis. Gynecol Endocrinol. 2007; 23(10): 567-573, doi: 10.1080/09513590701556921, indexed in $\mathrm{Pu}$ bmed: 17952761.

32. Suzumori N, Ozaki Y, Ogasawara M, et al. Increased concentrations of cathepsin D in peritoneal fluid from women with endometriosis. Mol Hum Reprod. 2001; 7(5): 459-462, indexed in Pubmed: 11331669.

33. Barrier BF, Sharpe-Timms KL. Expression of soluble adhesion molecules in sera of women with stage III and IV endometriosis. J Soc Gynecol Investig. 2002; 9(2): 98-101, indexed in Pubmed: 11963839.

34. Chen GTC, Tai CT, Yeh LS, et al. Identification of the cadherin subtypes present in the human peritoneum and endometriotic lesions: potential role for P-cadherin in the development of endometriosis. Mol Reprod Dev. 2002; 62(3): 289-294, doi: 10.1002/mrd.10121, indexed in Pubmed: 12112590.

35. Matalliotakis IM, Vassiliadis S, Goumenou AG, et al. Soluble ICAM-1 levels in the serum of endometriotic patients appear to be independent of medical treatment. J Reprod Immunol. 2001; 51(1): 9-19, indexed in Pubmed: 11438377.

36. Sipak-Szmigiel O, Włodarski P, Ronin-Walknowska E, et al. Serum and peritoneal fluid concentrations of soluble human leukocyte antigen, tumor necrosis factor alpha and interleukin 10 in patients with selected ovarian pathologies. J Ovarian Res. 2017; 10(1): 25, doi: 10.1186/s13048-017-0320-9, indexed in Pubmed: 28376925.

37. Cho S, Ahn YS, Choi YS, et al. Endometrial osteopontin mRNA expression and plasma osteopontin levels are increased in patients with endometriosis. Am J Reprod Immunol. 2009; 61(4): 286-293, doi: 10.1111/j.16000897.2009.00692.x, indexed in Pubmed: 19260859.

38. Lee DH, Kim SC, Joo JK, et al. Effects of 17 -estradiol on the release of monocyte chemotactic protein-1 and MAPK activity in monocytes stimulated with peritoneal fluid from endometriosis patients. J Obstet Gynaecol Res. 2012; 38(3): 516-525, doi: 10.1111/j.1447-0756.2011.01734.x, indexed in Pubmed: 22381103.

39. Khan KN, Kitajima M, Inoue T, et al. $17 \beta$-estradiol and lipopolysaccharide additively promote pelvic inflammation and growth of endometriosis. Reprod Sci. 2015; 22(5): 585-594, doi: 10.1177/1933719114556487, indexed in Pubmed: 25355803

40. Cunha-Filho JS, Gross JL, Bastos de Souza CA, et al. Physiopathological aspects of corpus luteum defect in infertile patients with mild/minimal endometriosis. J Assist Reprod Genet. 2003; 20(3): 117-121, indexed in Pubmed: 12735387.

41. Matarese G, Alviggi C, Sanna V, et al. Increased leptin levels in serum and peritoneal fluid of patients with pelvic endometriosis. J Clin Endocrinol Metab. 2000; 85(7): 2483-2487, doi: 10.1210/jcem.85.7.6703, indexed in Pubmed: 10902797.
42. Tao $\mathrm{Yu}$, Zhang Q, Huang $\mathrm{W}$, et al. The peritoneal leptin, MCP-1 and TNF- $\alpha$ in the pathogenesis of endometriosis-associated infertility. Am J Reprod Immunol. 2011; 65(4): 403-406, doi: 10.1111/j.1600-0897.2010.00920.x, indexed in Pubmed: 20825374.

43. Malhotra N, Karmakar D, Tripathi V, et al. Correlation of angiogenic cytokines-leptin and IL-8 in stage, type and presentation of endometriosis. Gynecol Endocrinol. 2012; 28(3): 224-227, doi: 10.3109/09513590.2011.593664, indexed in Pubmed: 21848410.

44. Keita M, Bessette P, Pelmus M, et al. Expression of interleukin-1 (IL-1) ligands system in the most common endometriosis-associated ovarian cancer subtypes. J Ovarian Res. 2010; 3 : 3, doi: 10.1186/1757-2215-3-3, indexed in Pubmed: 20181040.

45. Malutan AM, Drugan C, Drugan T, et al. The association between interleukin-4 -590C/T genetic polymorphism, IL-4 serum level, and advanced endometriosis. Cent Eur J Immunol. 2016; 41(2): 176-181, doi: 10.5114/ceji.2016.60992, indexed in Pubmed: 27536203.

46. Kang YJ, Jeung InC, Park A, et al. An increased level of IL-6 suppresses NK cell activity in peritoneal fluid of patients with endometriosis via regulation of SHP-2 expression. Hum Reprod. 2014; 29(10): 2176-2189, doi: 10.1093/humrep/deu172, indexed in Pubmed: 25035432.

47. Takamura M, Osuga Y, Izumi G, et al. Interleukin-17A is present in neutrophils in endometrioma and stimulates the secretion of growth-regulated oncogene- $\alpha$ (Gro- $\alpha)$ from endometrioma stromal cells. Fertility and Sterility. 2012; 98(5): 1218-1224.e2, doi: 10.1016/j.fertnstert.2012.07.1117.

48. Ahn SH, Edwards AK, Singh SS, et al. IL-17A Contributes to the Pathogenesis of Endometriosis by Triggering Proinflammatory Cytokines and Angiogenic Growth Factors. J Immunol. 2015; 195(6): 2591-2600, doi: 10.4049/jimmunol.1501138, indexed in Pubmed: 26259585.

49. Bedaiwy MA, Falcone T, Sharma RK, et al. Prediction of endometriosis with serum and peritoneal fluid markers: a prospective controlled trial. Hum Reprod. 2002; 17(2): 426-431, indexed in Pubmed: 11821289.

50. Kyama CM, Debrock S, Mwenda JM, et al. Potential involvement of the immune system in the development of endometriosis. Reprod Biol Endocrinol. 2003; 1: 123, doi: 10.1186/1477-7827-1-123, indexed in Pubmed: 14651748.

51. Rocha AL, Vieira EL, Maia LM, et al. Prospective Evaluation of a Panel of Plasma Cytokines and Chemokines as Potential Markers of Pelvic Endometriosis in Symptomatic Women. Gynecol Obstet Invest. 2016; 81(6): 512-517, doi: 10.1159/000443956, indexed in Pubmed: 26871558.

52. Guo Y, Chen Y, Liu LB, et al. IL-22 in the endometriotic milieu promotes the proliferation of endometrial stromal cells via stimulating the secretion of CCL2 and IL-8. Int J Clin Exp Pathol. 2013; 6(10): 2011-2020, indexed in Pubmed: 24133578.

53. Yang $\mathrm{Y}$, Zhang X, Zhou C, et al. Elevated immunoreactivity of RANTES and CCR1 correlate with the severity of stages and dysmenorrhea in women with deep infiltrating endometriosis. Acta Histochem. 2013; 115(5): 434-439, doi: 10.1016/j. acthis.2012.10.006, indexed in Pubmed: 23219091.

54. Shi X, Xu W, Dai HH, et al. The role of SRC1 and SRC2 in steroid-induced SDF1 expression in normal and ectopic endometrium. Reproduction. 2014; 147(6): 847-853, doi: 10.1530/ /REP-14-0027, indexed in Pubmed: 24586072.

55. Leconte M, Chouzenoux S, Nicco C, et al. Role of the CXCL12-CXCR4 axis in the development of deep rectal endometriosis. J Reprod Immunol. 2014; 103: 45-52, doi: 10.1016/j. jri.2013.12.121, indexed in Pubmed: 24534089. 
56. Veillat V, Carli C, Metz CN, et al. Macrophage migration inhibitory factor elicits an angiogenic phenotype in human ectopic endometrial cells and triggers the production of major angiogenic factors via CD44, CD74, and MAPK signaling pathways. J Clin Endocrinol Metab. 2010; 95(12): E403-E412, doi: 10.1210/jc.2010-0417, indexed in Pubmed: 20829186.

57. Kats R, Collette T, Metz CN, et al. Marked elevation of macrophage migration inhibitory factor in the peritoneal fluid of women with endometriosis. Fertil Steril. 2002; 78(1): 69-76, indexed in Pubmed: 12095493.

58. Inagaki J, Kondo A, Lopez LR, et al. Pregnancy loss and endometriosis: pathogenic role of anti-laminin-1 autoantibodies. Ann N Y Acad Sci. 2005; 1051: 174-184, doi: 10.1196/ /annals.1361.059, indexed in Pubmed: 16126957.

59. Gajbhiye R, Suryawanshi A, Khan S, et al. Multiple endometrial antigens are targeted in autoimmune endometriosis. Reprod Biomed Online. 2008; 16(6): 817-824, indexed in Pubmed: 18549691.

60. Heilier JF, Nackers F, Verougstraete V, et al. Increased dioxin-like compounds in the serum of women with peritoneal endometriosis and deep endometriotic (adenomyotic) nodules. Fertil Steril. 2005; 84(2): 305-312, doi: 10.1016/j.fertnstert.2005.04.001, indexed in Pubmed: 16084869.

61. Onda T, Ban S, Shimizu M, et al. CD10 is useful in demonstrating endometrial stroma at ectopic sites and in confirming a diagnosis of endometriosis. J Clin Pathol. 2002; 55(5): 391-392, indexed in Pubmed: 11986349.

62. Matsuzaki S, Darcha C. Epithelial to mesenchymal transition-like and mesenchymal to epithelial transition-like processes might be involved in the pathogenesis of pelvic endometriosis. Hum Reprod. 2012; 27(3): 712-721, doi: 10.1093/ /humrep/der442, indexed in Pubmed: 22215621.

63. Seppälä M, Koistinen H, Koistinen R, et al. Glycodelin in reproductive endocrinology and hormone-related cancer. Eur J Endocrinol. 2009; 160(2): 121-133, doi: 10.1530/EJE-08-0756, indexed in Pubmed: 19039086.

64. Meola J, Dentillo DB, Rosa e Silva JC, et al. Glycodelin expression in the endometrium of healthy women and in the eutopic and ectopic endometrium of women with endometriosis. Fertil Steril. 2009; 91(5): 1676-1680, doi: 10.1016/j. fertnstert.2008.02.158, indexed in Pubmed: 18402941.

65. Al-Jefout M, Dezarnaulds G, Cooper M, et al. Diagnosis of endometriosis by detection of nerve fibres in an endometrial biopsy: a double blind study. Hum Reprod. 2009; 24(12): 3019-3024, doi: 10.1093/humrep/dep275, indexed in Pubmed: 19690352.

66. Ramón L, Gilabert-Estellés J, Castelló R, et al. mRNA analysis of several components of the plasminogen activator and matrix metalloproteinase systems in endometriosis using a real-time quantitative RT-PCR assay. Hum Reprod. 2005; 20(1): 272-278, doi: 10.1093/humrep/deh571, indexed in $\mathrm{Pu}-$ bmed: 15579491.

67. Hudelist G, Lass H, Keckstein J, et al. Interleukin 1alpha and tissue-lytic matrix metalloproteinase- 1 are elevated in ectopic endometrium of patients with endometriosis. Hum Reprod. 2005; 20(6): 1695-1701, doi: 10.1093/humrep/deh794, indexed in Pubmed: 15746198.

68. Gilabert-Estellés J, Ramón LA, España F, et al. Expression of angiogenic factors in endometriosis: relationship to fibrinolytic and metalloproteinase systems. Hum Reprod. 2007; 22(8): 2120-2127, doi: 10.1093/humrep/dem149, indexed in Pubmed: 17609243.

69. Kim HOk, Yang KM, Kang IS, et al. Expression of CD44s, vascular endothelial growth factor, matrix metalloproteinase- 2 and $\mathrm{Ki}-67$ in peritoneal, rectovaginal and ovarian en- dometriosis. J Reprod Med. 2007; 52(3): 207-213, indexed in Pubmed: 17465288.

70. Gilabert-Estelles J, Ramon LA, España F, et al. Expression of the Fibrinolytic Components in Endometriosis. Pathophysiology of Haemostasis and Thrombosis. 2006; 35(1-2): 136-140, doi: 10.1159/000093556.

71. Poncelet C, Leblanc M, Walker-Combrouze F, et al. Expression of cadherins and CD44 isoforms in human endometrium and peritoneal endometriosis. Acta Obstet Gynecol Scand. 2002; 81(3): 195-203, indexed in Pubmed: 11966474.

72. Wu Y, Starzinski-Powitz A, Guo SW. Trichostatin A, a histone deacetylase inhibitor, attenuates invasiveness and reactivates E-cadherin expression in immortalized endometriotic cells. Reprod Sci. 2007; 14(4): 374-382, doi: 10.1177/1933719107302913, indexed in Pubmed: 17644810.

73. Shaco-Levy R, Sharabi S, Benharroch D, et al. Matrix metalloproteinases 2 and 9, E-cadherin, and beta-catenin expression in endometriosis, low-grade endometrial carcinoma and non-neoplastic eutopic endometrium. Eur J Obstet Gynecol Reprod Biol. 2008; 139(2): 226-232, doi: 10.1016/j. ejogrb.2008.01.004, indexed in Pubmed: 18295959.

74. Poncelet C, Cornelis F, Tepper M, et al. Expression of E- and $\mathrm{N}$-cadherin and CD44 in endometrium and hydrosalpinges from infertile women. Fertil Steril. 2010; 94(7): 2909-2912, doi: 10.1016/j.fertnstert.2010.04.055, indexed in Pubmed: 20605145

75. D'Amico F, Skarmoutsou E, Quaderno G, et al. Expression and localisation of osteopontin and prominin-1 (CD133) in patients with endometriosis. Int J Mol Med. 2013; 31(5): 1011-1016, doi: 10.3892/ijmm.2013.1325, indexed in Pubmed: 23545719.

76. Xue Q, Lin Z, Cheng YH, et al. Promoter methylation regulates estrogen receptor 2 in human endometrium and endometriosis. Biol Reprod. 2007; 77(4): 681-687, doi: 10.1095/ biolreprod.107.061804, indexed in Pubmed: 17625110.

77. Monsivais D, Dyson MT, Yin P, et al. ER $\beta$ - and prostaglandin E2-regulated pathways integrate cell proliferation via Raslike and estrogen-regulated growth inhibitor in endometriosis. Mol Endocrinol. 2014; 28(8): 1304-1315, doi: 10.1210/ /me.2013-1421, indexed in Pubmed: 24992181.

78. Chae U, Min JY, Kim SH, et al. Decreased Progesterone Receptor B/A Ratio in Endometrial Cells by Tumor Necrosis Factor-Alpha and Peritoneal Fluid from Patients with Endometriosis. Yonsei Med J. 2016; 57(6): 1468-1474, doi: 10.3349/ymj.2016.57.6.1468, indexed in Pubmed: 27593876.

79. Schmitz CR, Souza CA, Genro VK, et al. LH (Trp8Arg/ /Ile15Thr), LHR (insLQ) and FSHR (Asn680Ser) polymorphisms genotypic prevalence in women with endometriosis and infertility. J Assist Reprod Genet. 2015; 32(6): 991-997, doi: 10.1007/s10815-015-0477-3, indexed in Pubmed: 25935136.

80. Robin B, Planeix F, Sastre-Garau X, et al. Follicle-Stimulating Hormone Receptor Expression in Endometriotic Lesions and the Associated Vasculature: An Immunohistochemical Study. Reprod Sci. 2016; 23(7): 885-891, doi: 10.1177/1933719115623647, indexed in Pubmed: 26704526.

81. Gargett CE, Schwab KE, Zillwood RM, et al. Isolation and culture of epithelial progenitors and mesenchymal stem cells from human endometrium. Biol Reprod. 2009; 80(6): 1136-1145, doi: 10.1095/biolreprod.108.075226, indexed in Pubmed: 19228591.

82. Pacchiarotti A, Caserta D, Sbracia M, et al. Expression of oct-4 and c-kit antigens in endometriosis. Fertil Steril. 2011; 95(3): 1171-1173, doi: 10.1016/j.fertnstert.2010.10.029, indexed in Pubmed: 21075367. 
83. Meng X, Ichim TE, Zhong J, et al. Endometrial regenerative cells: a novel stem cell population. J Transl Med. 2007; 5: 57, doi: 10.1186/1479-5876-5-57, indexed in Pubmed: 18005405.

84. Yu CX, Song JH, Liang L. Correlation of changes of (non)exfoliated endometrial organelles and expressions of Musashi- 1 and $\beta$-catenin with endometriosis in menstrual period. Gynecol Endocrinol. 2014; 30(12): 861-867, doi: 10.3109/09513590.2014.955467, indexed in Pubmed: 25162724.

85. Cheng Y, Li L, Wang D, et al. Characteristics of Human Endometrium-Derived Mesenchymal Stem Cells and Their Tropism to Endometriosis. Stem Cells Int. 2017; 2017: 4794827, doi: 10.1155/2017/4794827, indexed in Pubmed: 28761446.

86. Pylväs M, Puistola U, Laatio L, et al. Elevated serum 8-OHdG is associated with poor prognosis in epithelial ovarian cancer. Anticancer Res. 2011; 31(4): 1411-1415, indexed in Pubmed: 21508394.

87. Sato N, Tsunoda H, Nishida M, et al. Loss of heterozygosity on 10q23.3 and mutation of the tumor suppressor gene PTEN in benign endometrial cyst of the ovary: possible sequence progression from benign endometrial cyst to endometrioid carcinoma and clear cell carcinoma of the ovary. Cancer Res. 2000; 60(24): 7052-7056, indexed in Pubmed: 11156411.

88. Dinulescu DM, Ince TA, Quade BJ, et al. Role of K-ras and Pten in the development of mouse models of endometriosis and endometrioid ovarian cancer. Nat Med. 2005; 11(1): 63-70, doi: 10.1038/nm1173, indexed in Pubmed: 15619626.

89. Govatati S, Kodati VL, Deenadayal M, et al. Mutations in the PTEN tumor gene and risk of endometriosis: a case-control study. Hum Reprod. 2014; 29(2): 324-336, doi: 10.1093/humrep/det387, indexed in Pubmed: 24154570.

90. Nezhat F, Cohen C, Rahaman J, et al. Comparative immunohistochemical studies of bcl-2 and $\mathrm{p} 53$ proteins in benign and malignant ovarian endometriotic cysts. Cancer. 2002; 94(11): 2935-2940, doi: 10.1002/cncr.10566, indexed in $\mathrm{Pu}-$ bmed: 12115382 .

91. Akahane T, Sekizawa A, Purwosunu Y, et al. The role of p53 mutation in the carcinomas arising from endometriosis. Int J Gynecol Pathol. 2007; 26(3): 345-351, doi: 10.1097/ /pgp.0b013e31802b41a8, indexed in Pubmed: 17581423.

92. Goumenou AG, Arvanitis DA, Matalliotakis IM, et al. Microsatellite DNA assays reveal an allelic imbalance in p16(Ink4), GALT, p53, and APOA2 loci in patients with endometriosis. Fertil Steril. 2001; 75(1): 160-165, indexed in Pubmed: 11163832.

93. Martini M, Ciccarone M, Garganese G, et al. Possible involvement of hMLH1, p16(INK4a) and PTEN in the malignant transformation of endometriosis. Int J Cancer. 2002; 102(4): 398-406, doi: 10.1002/ijc.10715, indexed in Pubmed: 12402310.

94. Wiegand KC, Shah SP, Al-Agha OM, et al. ARID1A mutations in endometriosis-associated ovarian carcinomas. N Engl J Med. 2010; 363(16): 1532-1543, doi: 10.1056/NEJMoa1008433, indexed in Pubmed: 20942669.

95. Chene G, Ouellet V, Rahimi K, et al. The ARID1A pathway in ovarian clear cell and endometrioid carcinoma, contiguous endometriosis, and benign endometriosis. Int J Gynaecol Obstet. 2015; 130(1): 27-30, doi: 10.1016/j.ijgo.2015.02.021, indexed in Pubmed: 25912412.

96. Chandler RL, Damrauer JS, Raab JR, et al. Coexistent ARID1A-PIK3CA mutations promote ovarian clear-cell tumorigenesis through pro-tumorigenic inflammatory cytokine signalling. Nat Commun. 2015; 6: 6118, doi: 10.1038/ /ncomms7118, indexed in Pubmed: 25625625.
97. Stewart CJR, Brennan BA, Chan T, et al. WT1 expression in endometrioid ovarian carcinoma with and without associated endometriosis. Pathology. 2008; 40(6): 592-599, doi: 10.1080/00313020802320697, indexed in Pubmed: 18752126.

98. Yotova I, Hsu E, Do C, et al. Epigenetic Alterations Affecting Transcription Factors and Signaling Pathways in Stromal Cells of Endometriosis. PLoS One. 2017; 12(1): e0170859, doi: 10.1371/journal.pone.0170859, indexed in Pubmed: 28125717.

99. Goumenou A, Panayiotides I, Matalliotakis I, et al. Bcl-2 and Bax expression in human endometriotic and adenomyotic tissues. Eur J Obstet Gynecol Reprod Biol. 2001; 99(2): 256-260, indexed in Pubmed: 11788183.

100. Meresman GF, Vighi S, Buquet RA, et al. Apoptosis and expression of Bcl-2 and Bax in eutopic endometrium from women with endometriosis. Fertil Steril. 2000; 74(4): 760-766, indexed in Pubmed: 11020520.

101. Ueda M, Yamashita Y, Takehara M, et al. Survivin Gene Expression in Endometriosis. The Journal of Clinical Endocrinology \& Metabolism. 2002; 87(7): 3452-3459, doi: 10.1210/ /jcem.87.7.8682.

102. Kato N, Sasou Si, Motoyama T. Expression of hepatocyte nuclear factor-1beta (HNF-1beta) in clear cell tumors and endometriosis of the ovary. Mod Pathol. 2006; 19(1): 83-89, doi: 10.1038/modpathol.3800492, indexed in Pubmed: 16258507.

103. Stewart CJR, Leung Y, Walsh MD, et al. KRAS mutations in ovarian low-grade endometrioid adenocarcinoma: association with concurrent endometriosis. Hum Pathol. 2012; 43(8): 1177-1183, doi: 10.1016/j.humpath.2011.10.009, indexed in Pubmed: 22305241.

104. Matsumoto T, Yamazaki M, Takahashi H, et al. Distinct $\beta$-catenin and PIK3CA mutation profiles in endometriosis-associated ovarian endometrioid and clear cell carcinomas. Am J Clin Pathol. 2015; 144(3): 452-463, doi: 10.1309/AJCPZ5T2POOFMQVN, indexed in Pubmed: 26276776.

105. Samartzis EP, Noske A, Dedes KJ, et al. ARID1A mutations and PI3K/AKT pathway alterations in endometriosis and endometriosis-associated ovarian carcinomas. Int J Mol Sci. 2013; 14(9): 18824-18849, doi: 10.3390/ijms140918824, indexed in Pubmed: 24036443.

106. Körner M, Burckhardt E, Mazzucchelli L. Higher frequency of chromosomal aberrations in ovarian endometriosis compared to extragonadal endometriosis: A possible link to endometrioid adenocarcinoma. Mod Pathol. 2006; 19(12): 1615-1623, doi: 10.1038/modpathol.3800699, indexed in Pubmed: 16980942.

107. Bischoff FZ, Heard M, Simpson JL. Somatic DNA alterations in endometriosis: high frequency of chromosome 17 and p53 loss in late-stage endometriosis. J Reprod Immunol. 2002; 55(1-2): 49-64, indexed in Pubmed: 12062821.

108. Okamoto A, Sehouli J, Yanaihara N, et al. Somatic copy number alterations associated with Japanese or endometriosis in ovarian clear cell adenocarcinoma. PLoS One. 2015; 10(2): e0116977, doi: 10.1371/journal.pone.0116977, indexed in Pubmed: 25658832.

109. Ali-Fehmi R, Khalifeh I, Bandyopadhyay S, et al. Patterns of loss of heterozygosity at 10q23.3 and microsatellite instability in endometriosis, atypical endometriosis, and ovarian carcinoma arising in association with endometriosis. Int J Gynecol Pathol. 2006; 25(3): 223-229, doi: 10.1097/01. pgp.0000192274.44061.36, indexed in Pubmed: 16810057.

110. Zhao ZZ, Nyholt DR, Thomas S, et al. Polymorphisms in the vascular endothelial growth factor gene and the risk of familial endometriosis. Mol Hum Reprod. 2008; 14(9): 531-538, doi: 10.1093/molehr/gan043, indexed in Pubmed: 18650217. 
111. Ammendola M, Pietropolli A, Saccucci P, et al. Acid phosphatase locus 1 genetic polymorphism, endometriosis, and allergy. Fertil Steril. 2008; 90(4): 1203-1205, doi: 10.1016/j. fertnstert.2007.10.014, indexed in Pubmed: 18490013.

112. Ammendola M, Bottini N, Pietropolli A, et al. Association between PTPN22 and endometriosis. Fertil Steril. 2008; 89(4): 993-994, doi: 10.1016/j.fertnstert.2007.04.008, indexed in Pubmed: 17624340 .

113. Novella-Maestre E, Carda C, Ruiz-Sauri A, et al. Identification and quantification of dopamine receptor 2 in human eutopic and ectopic endometrium: a novel molecular target for endometriosis therapy. Biol Reprod. 2010; 83(5): 866-873, doi: 10.1095/biolreprod.110.084392, indexed in $\mathrm{Pu}$ bmed: 20574053.

114. André GM, Barbosa CP, Teles JS, et al. Analysis of FOXP3 polymorphisms in infertile women with and without endometriosis. Fertil Steril. 2011; 95(7): 2223-2227, doi: 10.1016/j. fertnstert.2011.03.033, indexed in Pubmed: 21481380.

115. Frare AB, Barbosa AM, Costa IR, et al. GSTM1 and GSTT1 polymorphisms in endometriosis in women from Goiás, Brazil. Genet Mol Res. 2013; 12(3): 2764-2770, doi: 10.4238/2013. August.2.1, indexed in Pubmed: 23979901.

116. Liaqat I, Jahan N, Lone K, et al. Genetic polymorphisms associated with endometriosis in Pakistani women. J Endometr Pelvic Pain Disord. 2013; 5(4): 127-169, doi: 10.5301/ /je.5000165.

117. Sahmani M, Ghaleh TD, Darabi M, et al. I405V polymorphism of CETP gene and lipid profile in women with endometriosis. Gynecol Endocrinol. 2013; 29(7): 712-715, doi: 10.3109/09513590.2013.797396, indexed in Pubmed: 23772784.

118. Abutorabi R, Baradaran A, Sadat Mostafavi F, et al. Evaluation of Tumor Necrosis Factor Alpha Polymorphism Frequencies in Endometriosis. Int J Fertil Steril. 2015; 9(3): 329-337, indexed in Pubmed: 26644856.

119. Al-Rubae'i SHN, Naji TS, Turki KM. Common variation of the gene in Iraqi women with endometriosis disease. Genom Data. 2017; 11: 55-59, doi: 10.1016/j.gdata.2016.11.019, indexed in Pubmed: 27981034.

120. Kang S, Shi Yy, Li Y, et al. Association between genetic variants of the VEGFR-2 gene and the risk of developing endometriosis in Northern Chinese Women. Gynecol Obstet Invest. 2013; 76(1): 32-37, doi: 10.1159/000350665, indexed in Pubmed: 23635398.

121. Powell JE, Fung JN, Shakhbazov K, et al. Endometriosis risk alleles at $1 \mathrm{p} 36.12$ act through inverse regulation of $\mathrm{CDC} 42$ and LINC00339. Hum Mol Genet. 2016; 25(22): 5046-5058, doi: 10.1093/hmg/ddw320, indexed in Pubmed: 28171565.

122. Waldeyer W. Eierstock und Ei. Leipzig: Engeimann. 1870.

123. Russell WW. Aberrant portions of the Mullerian duct found in an ovary. Ovarian cysts of Mullerian origin. Bull. John Hopkins Hosp. 1899; 10: 8-10.

124. Iwanoff NS. IV. Drüsiges cystenhaltiges Uterusfibromyom complicirt durch Sarcom und Carcinom. (Adenofibromyoma cysticum sarcomatodes carcinomatosum). Gynecologic and Obstetric Investigation. 1898; 7(3): 295-300, doi: $10.1159 / 000280422$.

125. Lauche A. Die extragenitalen heterotopen Epithelwucherungen vom Bau der Uterusschleimhaut. (Fibroadenomatosis seroepidielialis). Virch Arch. 1923; 243: 298-373.

126. Suginami H. A reappraisal of the coelomic metaplasia theory by reviewing endometriosis occurring in unusual sites and instances. Am J Obstet Gynecol. 1991; 165(1): 214-218, indexed in Pubmed: 1853899.
127. Ridley JH. The histogenesis of endometriosis. A review of facts and fancies. Obstet Gynecol Survey. 1968; 23: 1-23.

128. Lauchlan SC, Lauchlan SC. The secondary Müllerian system. Obstet Gynecol Surv. 1972; 27(3): 133-146, indexed in Pubmed: 4614139.

129. Meyer R. Ueber den stand der Frage der Adenomyositis und Adenomyome in algemeinen und insbesondere iiber Adenomyositis serosoepithelialis und Adenomyometritis sarcomatosa. Zentralbl Gyndkol. 1919; 43: 745-750.

130. Novak E. Pelvic endometriosis. Spontaneous rupture of endometrial cysts, with a report of three cases. Am J Obstet Gynecol. 1931; 22(6): 826-837.

131. Levander G, Normann P. The Pathogenesis of Endometriosis an Experimental Study. Acta Obstetricia et Gynecologica Scandinavica. 1955; 34(4): 366-398, doi: $10.3109 / 00016345509158287$.

132. Merrill JA. Endometrial induction of endometriosis across Millipore filters. Am J Obstet Gynecol. 1966; 94(6): 780-790, indexed in Pubmed: 5948379.

133. Sampson J. Peritoneal endometriosis due to the menstrual dissemination of endometrial tissue into the peritoneal cavity. American Journal of Obstetrics and Gynecology. 1927; 14(4): 422-469, doi: 10.1016/s0002-9378(15)30003-x.

134. Haney AF. The pathogenesis and aetiology of endometriosis. In Thomas EJ, Rock JA, eds. Modern Approaches to Endometriosis. Dordrecht, Boston, London: Kluwer Academic Publishers; 1991:3-19.

135. Halban J. Metastatic hysteroadenosis. Wien Klin Wochenschr. 1924; 37: 1205-1206.

136. Halban J. Hysteroadenosis metastatica. Zentralbl Gyndkoi. 1925; 7: 387-391.

137. Sampson J. The development of the implantation theory for the origin of peritoneal endometriosis. American Journal of Obstetrics and Gynecology. 1940; 40(4): 549-557, doi: 10.1016/s0002-9378(40)91238-8.

138. Kitawaki J, Kado N, Ishihara H, et al. Endometriosis: the pathophysiology as an estrogen-dependent disease. J Steroid Biochem Mol Biol. 2002; 83(1-5): 149-155, indexed in Pubmed: 12650711.

139. Dun EC, Taylor RN, Wieser F. Advances in the genetics of endometriosis. Genome Med. 2010; 2(10): 75, doi: 10.1186/ /gm196, indexed in Pubmed: 20959029.

140. Cosín R, Gilabert-Estellés J, Ramón LA, et al. Influence of peritoneal fluid on the expression of angiogenic and proteolytic factors in cultures of endometrial cells from women with endometriosis. Hum Reprod. 2010; 25(2): 398-405, doi: 10.1093/humrep/dep419, indexed in Pubmed: 19945964.

141. Machado DE, Berardo PT, Palmero CY, et al. Higher expression of vascular endothelial growth factor (VEGF) and its receptor VEGFR-2 (Flk-1) and metalloproteinase-9 (MMP-9) in a rat model of peritoneal endometriosis is similar to cancer diseases. J Exp Clin Cancer Res. 2010; 29: 4, doi: 10.1186/1756-9966-29-4, indexed in Pubmed: 20085636.

142. Sotnikova NYu, Antsiferova YS, Posiseeva LV, et al. Mechanisms regulating invasiveness and growth of endometriosis lesions in rat experimental model and in humans. Fertil Steril. 2010; 93(8): 2701-2705, doi: 10.1016/j.fertnstert.2009.11.024, indexed in Pubmed: 20056200.

143. Bartosik D, Jacobs S, Kelly L. Endometrial tissue in peritoneal fluid. Fertility and Sterility. 1986; 46(5): 796-800, doi: 10.1016/s0015-0282(16)49813-4.

144. Kao AP, Wang KH, Chang CC, et al. Comparative study of human eutopic and ectopic endometrial mesenchymal stem cells and the development of an in vivo endometriotic invasion 
model. Fertil Steril. 2011; 95(4): 1308-13015.e1, doi: 10.1016/j. fertnstert.2010.09.064, indexed in Pubmed: 21047634.

145. Amalinei C, Cianga C, Balan R, et al. Immunohistochemical analysis of steroid receptors, proliferation markers, apoptosis related molecules, and gelatinases in non-neoplastic and neoplastic endometrium. Ann Anat. 2011; 193(1): 43-55, doi: 10.1016/j.aanat.2010.09.009, indexed in Pubmed: 21145716.

146. Keenan JA, Chen TT, Chadwell NL, et al. IL-1 beta, TNF-alpha, and IL-2 in peritoneal fluid and macrophage-conditioned media of women with endometriosis. Am J Reprod Immunol. 1995; 34(6): 381-385, indexed in Pubmed: 8607944.

147. Gottschalk C, Malberg K, Arndt M, et al. Matrix metalloproteinases and TACE play a role in the pathogenesis of endometriosis. Adv Exp Med Biol. 2000; 477: 483-486, indexed in Pubmed: 10849774.

148. Măluţan AM, Drugan T, Ciortea R, et al. Serum anti-inflammatory cytokines for the evaluation of inflammatory status in endometriosis. J Res Med Sci. 2015; 20(7): 668-674, doi: 10.4103/1735-1995.166215, indexed in Pubmed: 26622256.

149. Grund EM, Kagan D, Tran CA, et al. Tumor necrosis factor-alpha regulates inflammatory and mesenchymal responses via mitogen-activated protein kinase kinase, p38, and nuclear factor kappaB in human endometriotic epithelial cells. Mol Pharmacol. 2008; 73(5): 1394-1404, doi: 10.1124/ /mol.107.042176, indexed in Pubmed: 18252806.

150. Salmeri FM, Laganà AS, Sofo V, et al. Behavior of tumor necrosis factor- $\alpha$ and tumor necrosis factor receptor $1 /$ tumor necrosis factor receptor 2 system in mononuclear cells recovered from peritoneal fluid of women with endometriosis at different stages. Reprod Sci. 2015; 22(2): 165-172, doi: 10.1177/1933719114536472, indexed in Pubmed: 24844917.

151. Dawood MY, Khan-Dawood FS. Differential suppression of menstrual fluid prostaglandin F2a, prostaglandin E2, 6-keto prostaglandin F1a and thromboxane B2 by suprofen in women with primary dysmenorrhea. Prostaglandins Other Lipid Mediat. 2007; 83(1-2): 146-153, doi: 10.1016/j.prostaglandins.2006.10.009, indexed in Pubmed: 17259081.

152. Akoum A, Kong J, Metz C, et al. Spontaneous and stimulated secretion of monocyte chemotactic protein- 1 and macrophage migration inhibitory factor by peritoneal macrophages in women with and without endometriosis. Fertil Steril. 2002; 77(5): 989-994, indexed in Pubmed: 12009356.

153. Ouyang Z, Osuga Y, Hirota Y, et al. Interleukin-4 induces expression of eotaxin in endometriotic stromal cells. Fertil Steril. 2010; 94(1): 58-62, doi: 10.1016/j.fertnstert.2009.01.129, indexed in Pubmed: 19338989.

154. Morin M, Bellehumeur C, Therriault MJ, et al. Elevated levels of macrophage migration inhibitory factor in the peripheral blood of women with endometriosis. Fertil Steril. 2005; 83(4): 865-872, doi: 10.1016/j.fertnstert.2004.10.039, indexed in Pubmed: 15820792.

155. Khoufache K, Bazin S, Girard K, et al. Macrophage migration inhibitory factor antagonist blocks the development of endometriosis in vivo. PLoS One. 2012; 7(5): e37264, doi: 10.1371/journal.pone.0037264, indexed in Pubmed: 22649515.

156. Attar E, Tokunaga H, Imir G, et al. Prostaglandin E2 via steroidogenic factor-1 coordinately regulates transcription of steroidogenic genes necessary for estrogen synthesis in endometriosis. J Clin Endocrinol Metab. 2009; 94(2): 623-631, doi: 10.1210/jc.2008-1180, indexed in Pubmed: 19001523.

157. Banu SK, Lee J, Speights VO, et al. Cyclooxygenase-2 regulates survival, migration, and invasion of human endometriotic cells through multiple mechanisms. Endocrinology. 2008; 149(3): 1180-1189, doi: 10.1210/en.2007-1168, indexed in Pubmed: 18039779.
158. Carli C, Metz CN, Al-Abed Y, et al. Up-regulation of cyclooxygenase-2 expression and prostaglandin E2 production in human endometriotic cells by macrophage migration inhibitory factor: involvement of novel kinase signaling pathways. Endocrinology. 2009; 150(7): 3128-3137, doi: 10.1210/ /en.2008-1088, indexed in Pubmed: 19299454.

159. Chuang PC, Lin YJ, Wu MH, et al. Inhibition of CD36-dependent phagocytosis by prostaglandin E2 contributes to the development of endometriosis. Am J Pathol. 2010; 176(2): 850-860, doi: 10.2353/ajpath.2010.090551, indexed in Pubmed: 20035060

160. Jana S, Chatterjee K, Ray AK, et al. Regulation of Matrix Metalloproteinase-2 Activity by COX-2-PGE2-pAKT Axis Promotes Angiogenesis in Endometriosis. PLoS One. 2016; 11(10): e0163540, doi: 10.1371/journal.pone.0163540, indexed in Pubmed: 27695098.

161. Sikora J, Mielczarek-Palacz A, Kondera-Anasz Z. Role of natural killer cell activity in the pathogenesis of endometriosis. Curr Med Chem. 2011; 18(2): 200-208, indexed in Pubmed: 21110806.

162. Jeung I, Cheon K, Kim MR. Decreased Cytotoxicity of Peripheral and Peritoneal Natural Killer Cell in Endometriosis. Biomed Res Int. 2016; 2016: 2916070, doi: 10.1155/2016/2916070, indexed in Pubmed: 27294113.

163. Oosterlynck DJ, Cornillie FJ, Waer M, et al. Women with endometriosis show a defect in natural killer activity resulting in a decreased cytotoxicity to autologous endometrium. Fertil Steril. 1991; 56(1): 45-51, indexed in Pubmed: 2065804.

164. Stanic AK, Kim M, Styer AK, et al. Dendritic cells attenuate the early establishment of endometriosis-like lesions in a murine model. Reprod Sci. 2014; 21(10): 1228-1236, doi: 10.1177/1933719114525267, indexed in Pubmed: 24594835.

165. Podgaec S, Abrao MS, Dias JA, et al. Endometriosis: an inflammatory disease with a $\mathrm{Th} 2 \mathrm{immune}$ response component. Hum Reprod. 2007; 22(5): 1373-1379, doi: 10.1093/humrep/ /del516, indexed in Pubmed: 17234676.

166. Viganó P, Pardi R, Magri B, et al. Expression of intercellular adhesion molecule-1 (ICAM-1) on cultured human endometrial stromal cells and its role in the interaction with natural killers. Am J Reprod Immunol. 1994; 32(3): 139-145, indexed in Pubmed: 7880394.

167. Maeda N, Izumiya C, Oguri H, et al. Aberrant expression of intercellular adhesion molecule-1 and killer inhibitory receptors induces immune tolerance in women with pelvic endometriosis. Fertil Steril. 2002; 77(4): 679-683, indexed in Pubmed: 11937115.

168. Nishida M, Nasu K, Ueda T, et al. Endometriotic cells are resistant to interferon-gamma-induced cell growth inhibition and apoptosis: a possible mechanism involved in the pathogenesis of endometriosis. Mol Hum Reprod. 2005; 11(1): 29-34, doi: 10.1093/molehr/gah133, indexed in Pubmed: 15579658.

169. Drosdzol-Cop A, Skrzypulec-Plinta V. Selected cytokines and glycodelin A levels in serum and peritoneal fluid in girls with endometriosis. J Obstet Gynaecol Res. 2012; 38(10): 1245-1253, doi: 10.1111/j.1447-0756.2012.01860.x, indexed in Pubmed: 22563871.

170. Kocbek V, Grandi G, Blank F, et al. TNF $\alpha$-induced IKK $\beta$ complex activation influences epithelial, but not stromal cell survival in endometriosis. Mol Hum Reprod. 2016; 22(11): 768-777, doi: 10.1093/molehr/gaw054, indexed in Pubmed: 27542948

171. Veillat V, Sengers V, Metz CN, et al. Macrophage migration inhibitory factor is involved in a positive feedback loop increasing aromatase expression in endometriosis. Am J Pathol. 
2012; 181(3): 917-927, doi: 10.1016/j.ajpath.2012.05.018, indexed in Pubmed: 22759564.

172. Rakhila H, Girard K, Leboeuf M, et al. Macrophage migration inhibitory factor is involved in ectopic endometrial tissue growth and peritoneal-endometrial tissue interaction in vivo: a plausible link to endometriosis development. PLoS One. 2014; 9(10): e110434, doi: 10.1371/journal.pone.0110434, indexed in Pubmed: 25329068.

173. Li Y, Adur MK, Kannan A, et al. Progesterone Alleviates Endometriosis via Inhibition of Uterine Cell Proliferation, Inflammation and Angiogenesis in an Immunocompetent Mouse Model. PLoS One. 2016; 11(10): e0165347, doi: 10.1371/journal.pone.0165347, indexed in Pubmed: 27776183.

174. Xue Q, Lin Z, Cheng YH, et al. Promoter methylation regulates estrogen receptor 2 in human endometrium and endometriosis. Biol Reprod. 2007; 77(4): 681-687, doi: 10.1095/ /biolreprod.107.061804, indexed in Pubmed: 17625110.

175. Han SJ, Jung SY, Wu SP, et al. Estrogen Receptor $\beta$ Modulates Apoptosis Complexes and the Inflammasome to Drive the Pathogenesis of Endometriosis. Cell. 2015; 163(4): 960-974, doi: 10.1016/j.cell.2015.10.034, indexed in Pubmed: 26544941.

176. Arosh JA, Lee J, Balasubbramanian D, et al. Molecular and preclinical basis to inhibit PGE2 receptors EP2 and EP4 as a novel nonsteroidal therapy for endometriosis. Proc Natl Acad Sci U S A. 2015; 112(31): 9716-9721, doi: 10.1073 /pnas.1507931112, indexed in Pubmed: 26199416.

177. Lebovic DI, Bentzien F, Chao VA, et al. Induction of an angiogenic phenotype in endometriotic stromal cell cultures by interleukin-1beta. Mol Hum Reprod. 2000; 6(3): 269-275, indexed in Pubmed: 10694276.

178. Rocha AL, Carrarelli P, Novembri R, et al. Activin A stimulates interleukin 8 and vascular endothelial growth factor release from cultured human endometrial stromal cells: possible implications for the pathogenesis of endometriosis. Reprod Sci. 2012; 19(8): 832-838, doi: 10.1177/1933719111434542, indexed in Pubmed: 22477338.

179. Piva M, Sharpe-Timms KL. Peritoneal endometriotic lesions differentially express a haptoglobin-like gene. Mol Hum Reprod. 1999; 5(1): 71-78, indexed in Pubmed: 10050665.

180. Suzumori N, Zhao XXi, Suzumori K. Elevated angiogenin levels in the peritoneal fluid of women with endometriosis correlate with the extent of the disorder. Fertil Steril. 2004 82(1): 93-96, doi: 10.1016/j.fertnstert.2003.11.043, indexed in Pubmed: 15236995.

181. Chung HW, Wen Y, Choi EA, et al. Pleiotrophin (PTN) and midkine (MK) mRNA expression in eutopic and ectopic endometrium in advanced stage endometriosis. Mol Hum Reprod. 2002; 8(4): 350-355, indexed in Pubmed: 11912283.

182. Maas JW, Calhaz-Jorge C, ter Riet G, et al. Tumor necrosis factor-alpha but not interleukin-1 beta or interleukin- 8 concentrations correlate with angiogenic activity of peritoneal fluid from patients with minimal to mild endometriosis. Fertil Steril. 2001; 75(1): 180-185, indexed in Pubmed: 11163835.

183. Zucchini C, De Sanctis P, Facchini C, et al. Performance of Circulating Placental Growth Factor as A Screening Marker for Diagnosis of Ovarian Endometriosis: A Pilot Study. Int J Fertil Steril. 2016; 9(4): 483-489, indexed in Pubmed: 26985335.

184. Sotnikova NYu, Antsiferova YS, Posiseeva LV, et al. Mechanisms regulating invasiveness and growth of endometriosis lesions in rat experimental model and in humans. Fertil Steril. 2010; 93(8): 2701-2705, doi: 10.1016/j.fertnstert.2009.11.024, indexed in Pubmed: 20056200.
185. Takehara M, Ueda M, Yamashita Y, et al. Vascular endothelial growth factor $\mathrm{A}$ and $\mathrm{C}$ gene expression in endometriosis. Hum Pathol. 2004; 35(11): 1369-1375, doi: 10.1016/j. humpath.2004.07.020, indexed in Pubmed: 15668894.

186. Young VJ, Ahmad SF, Brown JK, et al. Peritoneal VEGF-A expression is regulated by TGF- $\beta 1$ through an ID1 pathway in women with endometriosis. Sci Rep. 2015; 5: 16859, doi: 10.1038/srep16859, indexed in Pubmed: 26577912.

187. Inan S, Kuscu NK, Vatansever S, et al. Increased vascular surface density in ovarian endometriosis. Gynecol Endocrinol. 2003; 17(2): 143-150, indexed in Pubmed: 12737676.

188. Alcázar JL, García-Manero M. Ovarian endometrioma vascularization in women with pelvic pain. Fertil Steril. 2007; 87(6): 1271-1276, doi: 10.1016/j.fertnstert.2006.11.106, indexed in Pubmed: 17336965.

189. Selam B, Kayisli UA, Garcia-Velasco JA, et al. Regulation of fas ligand expression by IL-8 in human endometrium. J Clin Endocrinol Metab. 2002; 87(8): 3921-3927, doi: 10.1210/jcem.87.8.8713, indexed in Pubmed: 12161534.

190. Greenberg LH, Slayden OvD. Human endometriotic xenografts in immunodeficient RAG-2/gamma(c)KO mice. Am J Obstet Gynecol. 2004; 190(6): 1788-95; discussion 1795, doi: 10.1016/j.ajog.2004.02.047, indexed in Pubmed: 15284801.

191. Nap AW, Dunselman GAJ, Griffioen AW, et al. Angiostatic agents prevent the development of endometriosis-like lesions in the chicken chorioallantoic membrane. Fertil Steril. 2005; 83(3): 793-795, doi: 10.1016/j.fertnstert.2004.06.080, indexed in Pubmed: 15749522.

192. Masuda H, Maruyama T, Hiratsu E, et al. Noninvasive and real-time assessment of reconstructed functional human endometrium in NOD/SCID/gamma c(null) immunodeficient mice. Proc Natl Acad Sci U S A. 2007; 104(6): 1925-1930, doi: 10.1073/pnas.0604310104, indexed in Pubmed: 17261813

193. Styer AK, Sullivan BT, Puder M, et al. Ablation of leptin signaling disrupts the establishment, development, and maintenance of endometriosis-like lesions in a murine model. Endocrinology. 2008; 149(2): 506-514, doi: 10.1210/en.2007-1225, indexed in Pubmed: 17962343.

194. Juhasz-Böss I, Hofele A, Lattrich C, et al. Matrix metalloproteinase messenger RNA expression in human endometriosis grafts cultured on a chicken chorioallantoic membrane. Fertil Steril. 2010; 94(1): 40-45, doi: 10.1016/j.fertnstert.2009.02.052, indexed in Pubmed: 19345347.

195. Maruyama T, Masuda H, Ono M, et al. Human uterine stem/ /progenitor cells: their possible role in uterine physiology and pathology. Reproduction. 2010; 140(1): 11-22, doi: 10.1530/ /REP-09-0438, indexed in Pubmed: 20457595.

196. Burns KA, Rodriguez KF, Hewitt SC, et al. Role of estrogen receptor signaling required for endometriosis-like lesion establishment in a mouse model. Endocrinology. 2012; 153(8): 3960-3971, doi: 10.1210/en.2012-1294, indexed in Pubmed: 22700766.

197. Greaves E, Cousins FL, Murray A, et al. A novel mouse model of endometriosis mimics human phenotype and reveals insights into the inflammatory contribution of shed endometrium. Am J Pathol. 2014; 184(7): 1930-1939, doi: 10.1016/j. ajpath.2014.03.011, indexed in Pubmed: 24910298.

198. Maeda N. Role of NK cells and HLA-G in endometriosis. Frontiers in Bioscience. 2012; S4(4): 1568-1581, doi: 10.2741/ /s353.

199. Goumenou AG, Matalliotakis IM, Tzardi M, et al. Apoptosis and differential expression of apoptosis-related proteins in endometriotic glandular and stromal cells. J Soc Gynecol 
Investig. 2004; 11(5): 318-322, doi: 10.1016/j.jsgi.2004.02.005, indexed in Pubmed: 15219886.

200. Wang XQ, Yu J, Luo XZ, et al. The high level of RANTES in the ectopic milieu recruits macrophages and induces their tolerance in progression of endometriosis. $\mathrm{J}$ Mol Endocrinol. 2010; 45(5): 291-299, doi: 10.1677/JME-09-0177, indexed in Pubmed: 20732991.

201. Mori S, Matsuzaki K, Yoshida K, et al. TGF-beta and HGF transmit the signals through JNK-dependent Smad2/3 phosphorylation at the linker regions. Oncogene. 2004; 23(44): 7416-7429, doi: 10.1038/sj.onc.1207981, indexed in Pubmed: 15326485 .

202. Hull ML, Johan MZ, Hodge WL, et al. Host-derived TGFB1 deficiency suppresses lesion development in a mouse model of endometriosis. Am J Pathol. 2012; 180(3): 880-887, doi: 10.1016/j.ajpath.2011.11.013, indexed in Pubmed: 22210480.

203. Sampson J. Peritoneal endometriosis due to the menstrual dissemination of endometrial tissue into the peritoneal cavity. American Journal of Obstetrics and Gynecology. 1927; 14(4): 422-469, doi: 10.1016/s0002-9378(15)30003-x.

204. Pearce CL, Templeman C, Rossing MA, et al. Ovarian Cancer Association Consortium. Association between endometriosis and risk of histological subtypes of ovarian cancer: a pooled analysis of case-control studies. Lancet Oncol. 2012; 13(4): 385-394, doi: 10.1016/S1470-2045(11)70404-1, indexed in Pubmed: 22361336.

205. Yu HC, Lin CY, Chang WC, et al. Increased Association Between Endometriosis and Endometrial Cancer. International Journal of Gynecological Cancer. 2015; 25(3): 447-452, doi: 10.1097/igc.0000000000000384.

206. Kobayashi H, Sumimoto K, Moniwa N, et al. Risk of developing ovarian cancer among women with ovarian endometrioma: a cohort study in Shizuoka, Japan. Int J Gynecol Cancer. 2007; 17(1): 37-43, doi: 10.1111/j.1525-1438.2006.00754.x, indexed in Pubmed: 17291229.

207. Kuo KT, Mao TL, Chen Xu, et al. Frequent activating mutations of PIK3CA in ovarian clear cell carcinoma. Am J Pathol. 2009; 174(5): 1597-1601, doi: 10.2353/ajpath.2009.081000, indexed in Pubmed: 19349352.

208. Kajihara H, Yamada Y, Kanayama S, et al. The role of hepatocyte nuclear factor-1beta in the pathogenesis of clear cell carcinoma of the ovary. Int J Gynecol Cancer. 2009; 19(3): 471-479, doi: 10.1111/IGC.0b013e3181a19eca, indexed in Pubmed: 19407577.

209. Jones S, Wang TL, Shih IM, et al. Frequent mutations of chromatin remodeling gene ARID1A in ovarian clear cell carcinoma. Science. 2010; 330(6001): 228-231, doi: 10.1126/ /science.1196333, indexed in Pubmed: 20826764.

210. Keita M, AinMelk Y, Pelmus M, et al. Endometrioid ovarian cancer and endometriotic cells exhibit the same alteration in the expression of interleukin-1 receptor II: to a link between endometriosis and endometrioid ovarian cancer. J Obstet Gynaecol Res. 2011; 37(2): 99-107, doi: 10.1111/j.14470756.2010.01320.x, indexed in Pubmed: 21083841.

211. Worley MJ, Liu S, Hua Y, et al. Molecular changes in endometriosis-associated ovarian clear cell carcinoma. Eur J Cancer. 2015; 51(13): 1831-1842, doi: 10.1016/j.ejca.2015.05.011, indexed in Pubmed: 26059197.

212. Zhao C, Wu LSF, Barner R. Pathogenesis of ovarian clear cell adenofibroma, atypical proliferative (borderline) tumor, and carcinoma: clinicopathologic features of tumors with endometriosis or adenofibromatous components support two related pathways of tumor development. J Cancer. 2011; 2 : 94-106, indexed in Pubmed: 21479128.
213. Bayramoğlu H, Düzcan E. Atypical epithelial changes and mutant p53 gene expression in ovarian endometriosis. Pathol Oncol Res. 2001; 7(1): 33-38, indexed in Pubmed: 11349218.

214. Amemiya S, Sekizawa A, Otsuka J, et al. Malignant transformation of endometriosis and genetic alterations of K-ras and microsatellite instability. Int J Gynaecol Obstet. 2004; 86(3): 371-376, doi: 10.1016/j.ijgo.2004.04.036, indexed in Pubmed: 15325855.

215. Otsuka J, Okuda T, Sekizawa A, et al. K-ras mutation may promote carcinogenesis of endometriosis leading to ovarian clear cell carcinoma. Med Electron Microsc. 2004; 37(3): 188-192, doi: 10.1007/s00795-004-0252-5, indexed in Pubmed: 15449112.

216. Hadfield RM. Linkage and association studies of the relationship between endometriosis and genes encoding the detoxification enzymes GSTM1, GSTT1 and CYP1A1. Molecular Human Reproduction. 2001; 7(11): 1073-1078, doi: 10.1093/ /molehr/7.11.1073.

217. Lousse JC, Defrère S, Colette S, et al. Expression of eicosanoid biosynthetic and catabolic enzymes in peritoneal endometriosis. Hum Reprod. 2010; 25(3): 734-741, doi: 10.1093/ /humrep/dep408, indexed in Pubmed: 20023295.

218. Furuya M, Tanaka R, Miyagi E, et al. Impaired CXCL4 expression in tumor-associated macrophages (TAMs) of ovarian cancers arising in endometriosis. Cancer Biol Ther. 2012;13(8): 671-680, doi: 10.4161/cbt.20084, indexed in Pubmed: 22555803.

219. Varma R, Rollason T, Gupta JK, et al. Endometriosis and the neoplastic process. Reproduction. 2004; 127(3): 293-304, doi: 10.1530/rep.1.00020, indexed in Pubmed: 15016949.

220. Yu HC, Lin CY, Chang WC, et al. Increased Association Between Endometriosis and Endometrial Cancer. International Journal of Gynecological Cancer. 2015; 25(3): 447-452, doi: 10.1097/igc.0000000000000384.

221. Treloar SA, Wicks J, Nyholt DR, et al. Genomewide linkage study in 1,176 affected sister pair families identifies a significant susceptibility locus for endometriosis on chromosome 10q26. Am J Hum Genet. 2005; 77(3): 365-376, doi: 10.1086/432960, indexed in Pubmed: 16080113.

222. Uno S, Zembutsu H, Hirasawa A, et al. A genome-wide association study identifies genetic variants in the CDKN2BAS locus associated with endometriosis in Japanese. Nat Genet. 2010; 42(8): 707-710, doi: 10.1038/ng.612, indexed in Pubmed: 20601957.

223. Painter JN, Anderson CA, Nyholt DR, et al. Genome-wide association study identifies a locus at $7 \mathrm{p} 15.2$ associated with endometriosis. Nat Genet. 2011; 43(1): 51-54, doi: 10.1038/ /ng.731, indexed in Pubmed: 21151130.

224. Nakayama K, Toki T, Nikaido T, et al. Genetic alterations in microsatellite marker sites among tumor suppressor genes in endometriosis. Gynecol Obstet Invest. 2001; 51(4): 240-242, doi: 10.1159/000058057, indexed in Pubmed: 11408734.

225. Hsieh YY, Chang CC, Tsai FJ, et al. Glutathione S-transferase $\mathrm{M} 1 *$ null genotype but not myeloperoxidase promoter G-463A polymorphism is associated with higher susceptibility to endometriosis. Mol Hum Reprod. 2004; 10(10): 713-717, doi: 10.1093/molehr/gah095, indexed in Pubmed: 15299090.

226. Suganuma I, Mori T, Ito F, et al. Peroxisome proliferator-activated receptor gamma, coactivator $1 \alpha$ enhances local estrogen biosynthesis by stimulating aromatase activity in endometriosis. J Clin Endocrinol Metab. 2014; 99(7): E1191-E1198, doi: 10.1210/jc.2013-2525, indexed in Pubmed: 24654751.

227. McConechy M, Ding J, Senz J, et al. Ovarian and endometrial endometrioid carcinomas have distinct CTNNB1 and PTEN mutation profiles. Modern Pathology. 2013; 27(1): 128-134, doi: 10.1038/modpathol.2013.107. 
228. Lai CR, Hsu CY, Chen YJ, et al. Ovarian cancers arising from endometriosis: a microenvironmental biomarker study including ER, HNF1ß, p53, PTEN, BAF250a, and COX-2 J Chin Med Assoc. 2013; 76(11): 629-634, doi: 10.1016/j. jcma.2013.07.008, indexed in Pubmed: 23962610.

229. Høgdall EVS, Christensen L, Høgdall CK, et al. Distribution of p53 expression in tissue from 774 Danish ovarian tumour patients and its prognostic significance in ovarian carcinomas. APMIS. 2008; 116(5): 400-409, doi: 10.1111/j.16000463.2008.00917.x, indexed in Pubmed: 18452430.

230. Bitler BG, Aird KM, Garipov A, et al. Synthetic lethality by targeting EZH2 methyltransferase activity in ARID1A-mutated cancers. Nat Med. 2015; 21(3): 231-238, doi: 10.1038/ $/ \mathrm{nm} .3799$, indexed in Pubmed: 25686104.

231. Guan B, Wang TL, Shih IM. ARID1A, a factor that promotes formation of SWI/SNF-mediated chromatin remodeling, is a tumor suppressor in gynecologic cancers. Cancer Res. 2011; 71(21): 6718-6727, doi: 10.1158/0008-5472.CAN-11-1562, indexed in Pubmed: 21900401.

232. Jones S, Li M, Parsons DW, et al. Somatic mutations in the chromatin remodeling gene ARID1A occur in several tumor types. Hum Mutat. 2012; 33(1): 100-103, doi: 10.1002/ /humu.21633, indexed in Pubmed: 22009941.

233. Samartzis EP, Samartzis N, Noske A, et al. Loss of ARID1A/ /BAF250a-expression in endometriosis: a biomarker for risk of carcinogenic transformation? Mod Pathol. 2012; 25(6): 885-892, doi: 10.1038/modpathol.2011.217, indexed in $\mathrm{Pu}-$ bmed: 22301703.

234. Wu H, Wang Ke, Liu W, et al. PTEN overexpression improves cisplatin-resistance of human ovarian cancer cells through upregulating KRT10 expression. Biochem Biophys Res Commun. 2014; 444(2): 141-146, doi: 10.1016/j.bbrc.2014.01.014, indexed in Pubmed: 24434152

235. Santulli P, Marcellin L, Chouzenoux S, et al. Role of the protein kinase BRAF in the pathogenesis of endometriosis. Expert Opin Ther Targets. 2016; 20(8): 1017-1029, doi: 10.1080/14728222.2016.1180367, indexed in Pubmed: 27087167.

236. Wang Y, van de, Fodde R, et al. Wnt/Beta-catenin and sex hormone signaling in endometrial homeostasis and cancer. Oncotarget. 2010; 1(7): 674-684.

237. Matsuzaki S, Darcha C. In vitro effects of a small-molecule antagonist of the $\mathrm{Tcf} / \mathrm{ß}$-catenin complex on endometrial and endometriotic cells of patients with endometriosis. PLoS One. 2013; 8(4): e61690, doi: 10.1371/journal.pone.0061690, indexed in Pubmed: 23626717.

238. Suryawanshi S, Vlad AM, Lin HM, et al. Plasma microRNAs as novel biomarkers for endometriosis and endometriosis-associated ovarian cancer. Clin Cancer Res. 2013; 19(5): 1213-1224, doi: 10.1158/1078-0432.CCR-12-2726, indexed in Pubmed: 23362326.

239. Yuan Dz, Yu Ll, Qu T, et al. Identification and characterization of progesterone- and estrogen-regulated MicroRNAs in mouse endometrial epithelial cells. Reprod Sci. 2015; 22(2): 223-234, doi: 10.1177/1933719114537714, indexed in Pubmed: 24925854

240. Burney RO, Hamilton AE, Aghajanova L, et al. MicroRNA expression profiling of eutopic secretory endometrium in women with versus without endometriosis. Mol Hum Reprod. 2009; 15(10): 625-631, doi: 10.1093/molehr/gap068, indexed in Pubmed: 19692421.

241. Petracco R, Grechukhina O, Popkhadze S, et al. MicroRNA 135 regulates HOXA10 expression in endometriosis. J Clin Endocrinol Metab. 2011; 96(12): E1925-E1933, doi: 10.1210/ /jc.2011-1231, indexed in Pubmed: 21956427.
242. Shen L, Yang S, Huang W, et al. MicroRNA23a and microRNA23b deregulation derepresses SF-1 and upregulates estrogen signaling in ovarian endometriosis. J Clin Endocrinol Metab. 2013; 98(4): 1575-1582, doi: 10.1210/jc.2012-3010, indexed in Pubmed: 23450049.

243. Wang WT, Zhao YN, Han BW, et al. Circulating microRNAs identified in a genome-wide serum microRNA expression analysis as noninvasive biomarkers for endometriosis. J Clin Endocrinol Metab. 2013; 98(1): 281-289, doi: 10.1210/ /jc.2012-2415, indexed in Pubmed: 23118427.

244. Graham A, Falcone T, Nothnick WB. The expression of microRNA-451 in human endometriotic lesions is inversely related to that of macrophage migration inhibitory factor (MIF) and regulates MIF expression and modulation of epithelial cell survival. Hum Reprod. 2015; 30(3): 642-652, doi: 10.1093/ /humrep/dev005, indexed in Pubmed: 25637622.

245. Mannis GN, Fehniger JE, Creasman JS, et al. Risk-reducing salpingo-oophorectomy and ovarian cancer screening in 1077 women after BRCA testing. JAMA Intern Med. 2013; 173(2): 96-103, doi: 10.1001/2013.jamainternmed.962, indexed in Pubmed: 23247828.

246. Jiang X, Hitchcock A, Bryan EJ, et al. Microsatellite analysis of endometriosis reveals loss of heterozygosity at candidate ovarian tumor suppressor gene loci. Cancer Res. 1996; 56(15): 3534-3539, indexed in Pubmed: 8758923.

247. Suryawanshi S, Huang X, Elishaev E, et al. Complement pathway is frequently altered in endometriosis and endometriosis-associated ovarian cancer. Clin Cancer Res. 2014; 20(23): 6163-6174, doi: 10.1158/1078-0432.CCR-14-1338, indexed in Pubmed: 25294912.

248. Harada T, Momoeda M, Taketani Y, et al. Low-dose oral contraceptive pill for dysmenorrhea associated with endometriosis: a placebo-controlled, double-blind, randomized trial. Fertil Steril. 2008; 90(5): 1583-1588, doi: 10.1016/j.fertnstert.2007.08.051, indexed in Pubmed: 18164001.

249. Petraglia F, Hornung D, Seitz C, et al. Reduced pelvic pain in women with endometriosis: efficacy of long-term dienogest treatment. Arch Gynecol Obstet. 2012; 285(1): 167-173, doi: 10.1007/s00404-011-1941-7, indexed in Pubmed: 21681516.

250. Mabuchi S, Altomare DA, Cheung M, et al. RAD001 inhibits human ovarian cancer cell proliferation, enhances cisplatin-induced apoptosis, and prolongs survival in an ovarian cancer model. Clin Cancer Res. 2007; 13(14): 4261-4270, doi: 10.1158/1078-0432. CCR-06-2770, indexed in Pubmed: 17634556.

251. Rauh-Hain JA, Penson RT. Potential benefit of Sunitinib in recurrent and refractory ovarian clear cell adenocarcinoma. Int J Gynecol Cancer. 2008; 18(5): 934-936, doi: 10.1111/j.1525-1438.2007.01156.x, indexed in Pubmed: 18081793.

252. Jin Y, Li Y, Pan L. The target therapy of ovarian clear cell carcinoma. Onco Targets Ther. 2014; 7: 1647-1652, doi: 10.2147/ /OTT.S49993, indexed in Pubmed: 25285014.

253. Littlepage LE, Adler AS, Kouros-Mehr H, et al. The transcription factor ZNF217 is a prognostic biomarker and therapeutic target during breast cancer progression. Cancer Discov. 2012; 2(7): 638-651, doi: 10.1158/2159-8290.CD-12-0093, indexed in Pubmed: 22728437.

254. Rahman MT, Nakayama K, Rahman M, et al. Gene amplification of ZNF217 located at chr20q13.2 is associated with lymph node metastasis in ovarian clear cell carcinoma. Anticancer Res. 2012; 32(8): 3091-3095, indexed in Pubmed: 22843878.

255. Lokman NA, Elder ASF, Ween MP, et al. Annexin A2 is regulated by ovarian cancer-peritoneal cell interactions and promotes metastasis. Oncotarget. 2013; 4(8): 1199-1211, doi: 10.18632/oncotarget.1122, indexed in Pubmed: 23945256. 
256. Shaw D, Clamp A, Jayson GC. Angiogenesis as a target for the treatment of ovarian cancer. Curr Opin Oncol. 2013; 25(5): 558-565, doi: 10.1097/CCO.0b013e328363e0da, indexed in Pubmed: 23942301.

257. Niu G, Wright KL, Huang M, et al. Constitutive Stat3 activity up-regulates VEGF expression and tumor angiogenesis. Oncogene. 2002; 21(13): 2000-2008, doi: 10.1038/sj.onc.1205260, indexed in Pubmed: 11960372.

258. Banu SK, Lee J, Speights VO, et al. Selective inhibition of prostaglandin $\mathrm{E} 2$ receptors EP2 and EP4 induces apoptosis of human endometriotic cells through suppression of ERK1/2, AKT, NFkappaB, and beta-catenin pathways and activation of intrinsic apoptotic mechanisms. Mol Endocrinol. 2009; 23(8): 1291-1305, doi: 10.1210/me.2009-0017, indexed in Pubmed: 19407222.

259. Matsuzaki S, Serada S, Morimoto A, et al. Annexin A4 is a promising therapeutic target for the treatment of platinum-resistant cancers. Expert Opin Ther Targets. 2014; 18(4): 403-414, doi: 10.1517/14728222.2014.882323, indexed in Pubmed: 24479491.

260. Alborzi S, Hamedi B, Omidvar A, et al. A comparison of the effect of short-term aromatase inhibitor (letrozole) and GnRH agonist (triptorelin) versus case control on pregnancy rate and symptom and sign recurrence after laparoscopic treatment of endometriosis. Arch Gynecol Obstet. 2011; 284(1): 105-110, doi: 10.1007/s00404-010-1599-6, indexed in Pubmed: 20661580.

261. Zhao Y, Gong P, Chen Y, et al. Dual suppression of estrogenic and inflammatory activities for targeting of endometriosis. Sci Transl Med. 2015; 7(271): 271ra9, doi: 10.1126/ /scitranslmed.3010626, indexed in Pubmed: 25609169.

262. Kulak J, Fischer C, Komm B, et al. Treatment with bazedoxifene, a selective estrogen receptor modulator, causes regression of endometriosis in a mouse model. Endocrinology. 2011; 152(8): 3226-3232, doi: 10.1210/en.2010-1010, indexed in Pubmed: 21586552.

263. Yao Z, Shen X, Capodanno I, et al. Validation of rat endometriosis model by using raloxifene as a positive control for the evaluation of novel SERM compounds. J Invest Surg. 2005; 18(4): 177-183, doi: 10.1080/08941930591004412, indexed in Pubmed: 16126628.

264. Zhang YX. Effect of mifepristone in the different treatments of endometriosis. Clin Exp Obstet Gynecol. 2016; 43(3): 350-353, indexed in Pubmed: 27328489.

265. Wagenfeld A, Bone W, Schwede W, et al. BAY 1002670: a novel, highly potent and selective progesterone receptor modulator for gynaecological therapies. Hum Reprod. 2013; 28(8): 2253-2264, doi: 10.1093/humrep/det247, indexed in Pubmed: 23739217.

266. Howe DC, Mount NM, Bess K, et al. The translational efficacy of a nonsteroidal progesterone receptor antagonist, 4-[3-cyclopropyl-1-(mesylmethyl)-5-methyl-1H-pyrazol-4-yl] oxy,-2,6-dimethylbenzonitrile (PF-02413873), on endometrial growth in macaque and human. J Pharmacol Exp Ther.
2011; 339(2): 642-653, doi: 10.1124/jpet.111.183848, indexed in Pubmed: 21849626.

267. Tanmahasamut $P$, Rattanachaiyanont M, Angsuwathana S, et al. Postoperative levonorgestrel-releasing intrauterine system for pelvic endometriosis-related pain: a randomized controlled trial. Obstet Gynecol. 2012; 119(3): 519-526, doi: 10.1097/ /AOG.0b013e31824264c3, indexed in Pubmed: 22314873.

268. Melis GB, Neri M, Corda V, et al. Overview of elagolix for the treatment of endometriosis. Expert Opin Drug Metab Toxicol. 2016; 12(5): 581-588, doi: 10.1517/17425255.2016.1171316, indexed in Pubmed: 27021205.

269. Magon N. Gonadotropin releasing hormone agonists: Expanding vistas. Indian J Endocrinol Metab. 2011; 15(4): 261-267, doi: 10.4103/2230-8210.85575, indexed in Pubmed: 22028996.

270. Streuli I, Ziegler Dde, Borghese B, et al. New treatment strategies and emerging drugs in endometriosis. Expert Opinion on Emerging Drugs. 2012; 17(1): 83-104, doi: 10.1517/14728214.2012.668885.

271. Ren XU, Wang Y, Xu G, et al. Effect of rapamycin on endometriosis in mice. Exp Ther Med. 2016; 12(1): 101-106, doi: 10.3892/etm.2016.3280, indexed in Pubmed: 27347023.

272. Ma Y, He YL. Study of an antiangiogenesis gene therapy with endostatin on endometriosis in the nude mouse model. Clin Exp Obstet Gynecol. 2014; 41(3):328-334, indexed in Pubmed: 24992787.

273. Dabrosin C, Gyorffy S, Margetts P, et al. Therapeutic effect of angiostatin gene transfer in a murine model of endometriosis. Am J Pathol. 2002; 161(3): 909-918, doi: 10.1016/S00029440(10)64251-4, indexed in Pubmed: 12213719.

274. Nap AW, Griffioen AW, Dunselman GAJ, et al. Antiangiogenesis therapy for endometriosis. J Clin Endocrinol Metab. 2004; 89(3): 1089-1095, doi: 10.1210/jc.2003-031406, indexed in Pubmed: 15001592.

275. Soysal D, Kızıldağ S, Saatı B, et al. A novel angiogenesis inhibitor bevacizumab induces apoptosis in the rat endometriosis model. Balkan J Med Genet. 2014; 17(2): 73-80, doi: 10.2478/bjmg-2014-0077, indexed in Pubmed: 25937801.

276. Olivares CN, Bilotas MA, Ricci AG, et al. Anastrozole and celecoxib for endometriosis treatment, good to keep them apart? Reproduction. 2013; 145(2): 119-126, doi: 10.1530/ /REP-12-0386, indexed in Pubmed: 23148086.

277. Hirakawa T, Nasu K, Aoyagi Y, et al. Arcyriaflavin a, a cyclin D1-cyclin-dependent kinase4 inhibitor, induces apoptosis and inhibits proliferation of human endometriotic stromal cells: a potential therapeutic agent in endometriosis. Reprod Biol Endocrinol. 2017; 15(1): 53, doi: 10.1186/s12958-017-0272-3, indexed in Pubmed: 28720098.

278. Park S, Lim W, Bazer F, et al. Apigenin induces ROS-dependent apoptosis and ER stress in human endometriosis cells. Journal of Cellular Physiology. 2017; 233(4): 3055-3065, doi: $10.1002 / j \mathrm{jcp} .26054$.

279. Celik O, Hascalik S, Elter K, et al. Combating endometriosis by blocking proteasome and nuclear factor-kappaB pathways. Hum Reprod. 2008; 23(11): 2458-2465, doi: 10.1093/humrep/ /den246, indexed in Pubmed: 18676981. 